\title{
Balkan Savaşları'nın Ardından Osmanlı ile Romanya'nın Politik Temasları ve Dâhiliye Nazırı Talat Bey'in Romanya Ziyaretleri
}

\author{
Political Relations of the Ottoman Empire and Romania Following the \\ Balkan Wars and the Minister of the Interior Talat Bey's Visit to Romania \\ Eminalp MALKOÇ*
}

\begin{abstract}
Özet
Dünyanın ilk büyük savaşına sürüklendiği süreçte Türk-Romen ilişkilerinde ilginç/farklı bir etkileşim süreci yaşanmıştı. Nitekim 1914 baharı, siyasal kaygıların şekillendirdiği resmi temaslara bağlı olarak iki ülke arasında yoğun bir yakınlaşma çabasına sahne olmuştu. Nisan ayında Romanyalı General Coanda, İstanbul'da çeşitli temaslarda bulunmuş; ardından Mayıs ayı içinde Talat Bey, Romanya ziyaretini tamamlamışıı. Bu ziyaret gündeme Türk-Romen ittifakını taşıyacaktı. Bu çalışma, arşiv belgeleri ve süreli yayınlarla diğer kaynaklara dayanarak Balkan Savaşları sonrasında 1914 bahar başlarından büyük savaşın ilk aylarına kadar uzanan Osmanlı Devleti ile Romanya'nın yakınlaşma çabalarını, Balkanların genel konjonktürü bağlamında inceleyerek Osmanlı Devleti'nin ittifak arayıșlarına katkıda bulunmayı amaçlamaktadır.
\end{abstract}

Anahtar Kelimeler: Birinci Dünya Savaşı, Romanya-Osmanlı Devleti İlişkileri, Romanya Gezileri, Talat Paşa

Abstract

In the period that the world went through during the first major war, there had been a time of intrigue in the Turkish-Romanian relations. The spring of 1914 witnessed an intense attempt for amity based on official contiguity between the two countries that was shaped by political considerations. In April, the Romanian general Coanda had several visits to İstanbul; then, in the same year, Talat Bey completed his visit to Romania in May. Based on archival documents, periodicals and other sources, this study aims to contribute to the search of the Ottoman State for alliance by examining within the general conjuncture of the Balkans the attempts of the Ottoman State with Romania after the Balkan Wars, starting from 1914 spring to the first months of the major war.

Keywords: First World War, Relations between Romania-Ottoman State, Romania Visits, Talat Pasha

\section{Giriș}

Balkan Savaşları son bulduğunda Osmanlı Devleti büyük bir toprak kaybına uğramıştır. Birinci Balkan Savaşı'nın ardından 30 Mayıs 1913 tarihinde Londra Anlaşması imzalanmış ve Osmanlı Devleti, Midye-Enez Hattı'na kadar çekilmek durumunda kalmıştır. Osmanlı Devleti'nin sadece Edirne'yi geri kazanabildiği İkinci Balkan Savaşı sırasında ise Bulgaristan'ın tüm cephelerde yenilmesi ve barış istemesi üzerine 10 Ağustos 1913 tarihinde Bükreș Antlaşması imzalanmıştır.

Bükreş Antlaşması ile Balkanların yeni statüsü büyük ölçüde belirlenmiştir. Balkanlarda yeni dengeler şekillenirken Bulgaristan Güney Dobruca'nın Romanya; Güney Makedonya ve Batı Trakya'nın büyük kısmının Yunanistan, Manastır ve Üsküp civarının Sırbistan tarafından alınışını izlemişti. Nihayet Bükreş Antlaşması ardında Sırbistan, Yunanistan ve Bulgaristan arasında Makedonya Sorunu, Türkiye ile Yunanistan arasında Adalar Meselesi, Romanya ile

\footnotetext{
* Dr. İstanbul Teknik Üniversitesi, malkocem@itu.edu.tr. Makalenin yazarı tarafından I. Dünya Savaşı'na giden süreçte resmi ve gayrı resmi boyutlarıyla Türk-Romen yakınlaşmasını konu alan bir bildiri Uluslararası I. Dünya Savaşı Sempozyumu'nda (İzmir, 12-15 Kasım 2015) sunulmuştur.
} 
Bulgaristan arasında Dobruca Sorunu ve Yunanistan ile Arnavutluk arasında Epir Meselesi'ni bırakmıştı. Bu arada süreç, Osmanlı Devleti'nin Bulgaristan ile İstanbul Antlaşması'nı, Yunanistan ile Atina Anlaşması'nı imzalamasıyla tamamlanacaktı1.

Balkanlıların Balkan Savaşları sonrasında Bükreş Anlaşması ile ortaya çıkan sorunlarla yüzleşmek zorunda kalarak gruplaştıkları daha da önemlisi dünyanın hızlı bir şekilde ilk büyük savaşına sürüklendiği bu dönemde Türk-Romen ilişkilerinde ilginç/farklı bir etkileşim süreci yaşanmıştı. Özellikle 1914 baharı, siyasal kaygıların şekillendirdiği resmi temaslara bağlı olarak iki ülke arasında yoğun bir yakınlaşma çabasına sahne olmuştu.

\section{İonescu'nun İstanbul Ziyaretleri}

Osmanlı-Romanya yakınlaşmasının temelleri, Balkan Savaşları sonrasında atılmıştı. Savaş sonrası düzeni oluşturacak ve Balkan Devletleri ile Osmanlı Devleti'nin ilişkilerini belirleyecek anlaşmaların hazırlanması çizgisinde Türk-Yunan görüşmeleri sürdürülürken Romanya Dahiliye Nazırı (İçişleri Bakanı) Tache Ionescu'nun Atina'ya ziyarette bulunması gündeme gelmiști ${ }^{2}$. Ionescu, 5 Kasım 1913'te -Yunanistan'da karșılama hazırlıklarının başladığı sıralarda- Romanya'dan ayrılmıştı ${ }^{3}$. İstanbul üzerinden Yunanistan'a geçerken Dahiliye Nazırı Talat Bey ile Meclis-i Ayan üyelerinden (eski Nafia Nazırı) Besarya Efendi, Ionescu'nun seyahat ettiği vapuru ziyaret etmişler ve kendisiyle yaklaşık bir saat görüşmüşlerdi.

Ionescu, İstanbul'da uzun süre kalmamakla birlikte basına açıklama yapma firsatı bulmuştu. Gazetelere Bükreş Konferansı'ndan beri Venizelos ile kararlaştırdıkları bu gezinin, ertelemelerden sonra ancak gerçekleştiğini söylemişti. Boğazların Osmanlı hakimiyetinde bulunmasının Romanya'nın menfaatine uygun düştügüunü belirterek her iki tarafın barışçı bir tutum içinde olduklarını düşündüğünü açıklamıştı. Osmanlı Devleti, Yunanistan ve Sırbistan arasında da bir barışın sağlanabileceği yönündeki ümitlerini ortaya koymuş; Romanya'nın Balkanlarda barıșı arzu ettiğini sözlerine eklemiști. Ayrıca Talat Bey ile ilk kez bir araya geldiğini hatırlatan Ionescu, tanışmaktan duyduğu memnuniyetini ifade etmiş; Talat Bey hakkında övgü dolu sözler kullanmışt1 ${ }^{4}$.

Tache Ionescu, Yunanistan'a ulaşmak üzere İstanbul'dan ayrıldığında, gazetelere birkaç gün sonra Osmanlı başkentine gelerek iki gün kalacağı haberleri yansımışt1 ${ }^{5}$. Öte yandan Tercüman-ı Hakikat gibi gazeteler onun Yunanistan ziyaretini izlemişti. İlginçtir; aynı dönemde Romanya Dahiliye Nazırı'nın Türkiye ile Yunanistan'ın anlaşması için çaba sarf edeceği hatta anlaşma sağlanmasında büyük rol oynayacağı söylemleri gazete sütunlarına taşınmışt ${ }^{6}$. Gazetelerin aktarımlarına göre Yunanistan'da da Türk-Yunan barışını arzu ettiklerini açıklayan Ionescu, orada bulunan Türk delegelerle görüşerek bir öneri gündeme getirmişti ${ }^{7}$. Bu arada 13 Kasım'da Osmanlı ile Yunanistan hükümetleri arasında anlaşma imzalandığı haberleri basına

\footnotetext{
${ }^{1}$ Mücahit Özçelik. (2012). 1918 Bükreş Antlaşması. Turkish Studies, Volume:4/4 Kasım/November, s.262. Adalar Meselesi'nin özünü Halil Bey, “Adalar, fiilen Yunanistan'ın işgalinde, fakat hukuken bizde idi” sözleriyle ortaya koymaktadır. "Eski Meclisi Mebusan Reisi Halil Menteşe'nin Hatıralar1-30”, Cumhuriyet, 17 Kasım 1946, No:7991, s.2.

${ }^{2}$ Tercüman-ı Hakikat, 3 Teşrin-i Sani Efrenci 1913, No:11699, s.2.

${ }^{3}$ Tercüman-ı Hakikat, 5 Teşrin-i Sani Efrenci 1913, No:11701, s.2.

${ }^{4}$ Tercüman-ı Hakikat, 6 Teşrin-i Sani Efrenci 1913, No:11702, s.2.

${ }^{5}$ Tercüman-ı Hakikat, 7 Teşrin-i Sani Efrenci 1913, No:11703, s.2.

${ }^{6}$ Tercüman-ı Hakikat, 8 Teşrin-i Sani Efrenci 1913, No:11704, s.1.

${ }^{7}$ Bir Romen siyasetçi İstanbul'da yaptığı açıklamada "Mösyö Tache Ionescu'nun Türkiye ile Yunanistan'ın ihtilafinda 'namuslu bir simsar' olduğu kimse için bir sır değildir" diyecekti. Tercüman-ı Hakikat, 8 Teşrin-i Sani Efrenci 1913, No:11704, s.2; Tercüman-ı Hakikat, 9 Teşrin-i Sani Efrenci 1913, No:11705, s.2; Tercüman-ı Hakikat, 13 Teşrin-i Sani Efrenci 1913, No:11706, s.1-2,4. Anlaşma metni Tercüman-ı Hakikat tarafından 15 ve 19 Kasım'da yayınlanmıştı. Tercüman-ı Hakikat, 15 Teşrin-i Sani Efrenci 1913, No:11708, s.1-2; Tercüman-ı Hakikat, 19 Teşrin-i Sani Efrenci 1913, No:11712, s.3-4.
} 
konu olmuş ve sürecin ilerlemesinde Ionescu'nun da etkisinin bulunduğu üzerinde durulmuştu. Romanya Dahiliye Nazırı ise Yunanistan'dan ayrılarak İstanbul'a geçmişti. Bu dönem basınında bir "Balkan Itttihadı" ve Romanya'nın bu yöndeki çabalarını içeren haberler dikkat çekiciydi.

Tache Ionescu, İstanbul'a ulaştıktan sonra kendisini Talat Bey ziyaret etmişti. Ziyaret sırasında vapurda sabah kahvaltısı yapılmış ve kısa bir görüşme gerçekleştirilmişti. Öğle saatlerinde Talat Bey, misafir nazır şerefine ziyafet düzenlemişti ${ }^{8}$. İstanbul'da padişah tarafından huzura kabul edilen Ionescu, kendisiyle yapılan röportajda söz konusu ziyaretler dizisini şahsi olarak tanımlamış; bununla birlikte bir siyasi etkinin olduğunu da belirtmişti. $\mathrm{Bu}$ etkiyi, Romanya'nın barış arzusuna ve Talat Bey ile İstanbul'daki ilk görüşmesine bağlamıştı. Soru üzerine Türk-Romen ilişkilerine yönelik tanısını "Osmanll-Romanya münasebeti mükemmeldir" cümlesiyle ortaya koymuştu'. İstanbul'da Fener Patrikhanesi'ni ziyaret eden Ionescu, 15 Kasım 1913 günü İstanbul'dan ayrılmışt1 ${ }^{10}$. Bir Türk-Romen ittifakının Türk ya da yabancı yayın organlarında haber olmaya başladığı bu dönemde ${ }^{11}$ Talat Bey'in Romanya'ya ziyarette bulunacağı gündeme gelmişti. Ancak kısa süre içinde gazeteler, bu gezinin ertelendiğini haber yapmıșlard $1^{12}$.

\section{Büyük Savaş Öncesi Politik Temaslar ve Talat Bey’in İlk Romanya Ziyareti}

1914 baharı, Türk-Romen ilişkilerinde ilginç, farklı ve yoğun bir etkileşime sahne olmuştu. Türkiye ile Romanya' daki Darülfünun öğrencilerinin karşılıklı geziler düzenledikleri ve coşkunun hakim olduğu bu dönemde "Hiçbir memuriyet-i resmiyeyi haiz değilim"13 diyen General Coanda ${ }^{14}$, İstanbul'da çeşitli temaslar gerçekleştirmişti. Sadrazam Sait Halim ${ }^{15}$ ve Harbiye Nazırı Enver Paşalarla görüşen Coanda ${ }^{16}, 22$ Nisan günü Talat Bey’e veda ziyaretinde

\footnotetext{
${ }^{8}$ Tercüman-ı Hakikat, 14 Teşrin-i Sani Efrenci 1913, No:11707, s.1-3. Yusuf Hikmet Bayur, Romanya İçişleri Bakanı Ionescu'nun Atina'ya geldiği zaman aracılık yaptı̆̆ını ve taraflardan fedakarlıkta bulunmalarını istediğini; onun etkisiyle 14 Kasım 1913'te antlaşmanın imzalandığını yazmaktadır. Bazı anlaşma maddelerini de eserinde sıralamıştı. Yusuf H. Bayur. (1991). Türk Inkılâbı Tarihi. c.II/III, Türk Tarih Kurumu (TTK) Yayınları, Ankara, s.245.

${ }^{9}$ Tercüman-ı Hakikat, 15 Teşrin-i Sani Efrenci 1913, No:11708, s.2. Tercüman-ı Hakikat, Tan (Temps) gazetesinin bir makalesini yayınlamıştı. Burada da Ionescu ile Talat Bey'in ilk görüşmelerinin önemi üzerinde durulmuştu. Tercüman-ı Hakikat, 16 Teşrin-i Sani Efrenci 1913, No:11709, s.1. Bazı yabancı yayın organları sürecin sonuçlanmasında Romanya'nın etkisinin altını çizmişti. Tercüman-ı Hakikat, 21 Teşrin-i Sani Efrenci 1913, No:11714, s.1. Bazı dış kaynaklı haberlerde Ionescu'nun tali bir takım ihtilafların çözülmesine yardımcı olduğu vurgulanmıştı. Peyam, 22 Teşrin-i Sani Efrenci 1913, No:9, s.2.

${ }^{10}$ Tercüman-ı Hakikat, 16 Teşrin-i Sani Efrenci 1913, No:11709, s.3.

${ }^{11}$ Tercüman-ı Hakikat, 20 Teşrin-i Sani Efrenci 1913, No:11713, s.2; Peyam, 26 Teşrin-i Sani Efrenci 1913, No:13, s.2. Aynı dönemde Romanyalıların Talat Bey’e yönelik ilgileri artmıştı. Nitekim Tercüman-ı Hakikat gazetesine göre, Romanyalı mebuslardan Epoka gazetesinin müdürü Pizani (ya da Peyzani ?) İstanbul'a gelerek Talat Bey ile röportaj yapmıştı. Tercüman-ı Hakikat, 21 Teşrin-i Sani Efrenci 1913, No:11714, s.2.

12 Peyam, 24 Teşrin-i Sani Efrenci 1913, No:11, s.3.

${ }^{13}$ Sabah, 24 Nisan Efrenci 1914, No:8836, s.1.

${ }^{14}$ Coanda bazı gazetelerde eski Romanya Harbiye Nazırı bazılarında Erkan-ı Harbiye Reisi olarak tanıtılmıştı. Yusuf Hikmet Bayur ise Kral Carol'un başyaveri olduğunu belirtmektedir. Bayur, Adalar Meselesi'nde aracılık yaptığını (ki bu gazeteler takip edildiğinde de anlaşılmaktadır) ancak başarısız olduğunu kaydetmektedir. Bayur, a.g.e., s.266.

${ }^{15}$ Coanda, 21 Nisan'da Sait Halim Paşa'yı ziyaret etmiş ve Sait Halim Paşa da kendisinin kaldığı Pera Palas Oteli’nde iadeyi ziyarette bulunmuştu. Tasfir-i Efkâr, 22 Nisan 1914, No:1056, s.2.

${ }^{16}$ İkdam ve Sabah gazeteleri, Coanda'nın “refakatinde Romanya Hükümeti'nin Dersaadet Ateşemiliteri bulunduğu halde Saray-ı Hümayun'a azimetle suret-i hususiyede Huzur-l Şahane'ye kabul buyurulmuşdur" notunu düşmüştü. Yine 22 Nisan'da Talat Bey ile görüştüğü ve 23 Nisan'da İstanbul'dan ayrılacağı aktarılmıştı. İkdam, 23 Nisan Efrenci 1914, No:6167, s.2; İkdam, 24 Nisan Efrenci 1914, No:6168, s.2,3; Sabah, 23 Nisan Efrenci 1914, No:8835, s.2; Sabah, 24 Nisan Efrenci 1914, No:8836, s.1.
} 
bulunmuștu ${ }^{17}$. Bu ziyaret sırasında Talat Bey, General Coanda'nın sorusu üzerine "Bükreș' $i$ Meclis-i Mebusanı'nın güşadından sonra ziyaret edeceğini" belirtmişti. Coanda, İstanbul'dan ayrılmadan önce basına çeşitli demeçler vermekten geri durmayacakt1 ${ }^{18}$.

Coanda'nın ardından 4 Mayıs günü Romanya prenslerinden birinin 5 Mayıs'ta ayrılmak üzere İskenderiye'den İstanbul'a geldiği haberi basında yer alacakt ${ }^{19}$. Gündemde ise Dahiliye Nazırı Talat Bey'in Romanya'ya yapacağı gezi vardı. Gezi hakkında Osmanlı Sefiri Safa Bey, Romanya basınına demeç vermiş; Talat Bey'in gezisinin Romanyalı yetkililerin İstanbul ziyaretlerine karş1lık olduğunu ve bu gezinin iki ülke ilişkilerini olumlu yönde etkileyeceğini söylemişti. Dönemin gazetelerinde Talat Bey ile birlikte Harbiye Nazırı Enver Paşa'nın da Bükreş’i ziyaret edeceği hatta ziyaretin üç gün süreceği haberleriyle de karşılaşılmaktayd1 ${ }^{20}$. Ancak; Romanya basınından hareket eden Sabah gazetesinin 3 Mayıs $^{21}$ ve -yine Mayıs'1n ilk günlerinde- Tanin'in 9 Mayıs olarak ${ }^{22}$ tarihlendirdiği bu seyahat ertelenecekti. Gezinin ertelenmesinin nedeni Talat Paşa'nın Rus Çarı ile görüşmek üzere Livadia'ya gitmesiydi. Nitekim I. Dünya Savaşı arifesinde Osmanlı Devleti'nin Rusya'yla olan ilişskilerini geliştirmek amacıyla Dahiliye Nazırı Talat Bey başkanlığındaki bir heyet Livadia'da bulunan Rus Çarını ziyaret etmişti. Türk heyeti, 9 Mayıs'ta İstanbul'dan ayrıldığından Talat Bey'in önceden planlanmış Romanya gezisi ertelenmişti ${ }^{23}$.

Romanya seyahatinin ertelenme gerekçesi, Romanya Kralı Carol'un Tuna civarında gezide bulunması ve bu seyahatin 23 Mayıs'a kadar sürecek olması şeklinde basına yansımıştı. Bundan dolayı gazeteler, Talat Bey'in planlanan şekilde Livadia'dan Bükreş'e geçmeyeceğini,

\footnotetext{
${ }^{17}$ Tasfir-i Efkâr, 23 Nisan 1914, No:1057, s.3. Talat Bey, 23 Nisan'da kaldığı otele giderek Coanda'ya iadeyi ziyarette bulunmuştu. Sabah, 24 Nisan Efrenci 1914, No:8836, s.2.

${ }^{18}$ Coanda, Ístanbul gazetesi muhabiriyle röportaj yapmıştı. Burada Enver Paşa’yı ziyarete gittiğinde Talat Bey ile karşılaştığını, ayrıca Talat Bey için Tache Ionescu'nun verdiği tavsiye mektubunun yanında bulunduğunu söylemişti. Muhabirin sorularına karşılık Osmanlı'nın Balkanlardaki konumu, Bükreş Muahedenamesi, TürkRomen dostluğu, Türk-Yunan ilișkileri ve Adalar Meselesi gibi konularda düşüncelerini açıklamıștı. Venizelos ile görüştüğünü de aktarmıştı. Sabah, 24 Nisan Efrenci 1914, No:8836, s.1,2; Ikdam, 24 Nisan Efrenci 1914, No:6168, s.2-3. Coanda, Tasfir-i Efkâr muhabirine Pera Palas Oteli'nden ayrılmak üzere iken açıklama yapmış; Mısır'a kızını ziyarete gittiğini, bu arada Yunanistan'da Venizelos ile görüştüğünü ve Romanya'ya dönüşü sırasında İstanbul'a uğradığını söylemişti. Ziyaretinin özel bir anlam taşımadığını vurgulayan Coanda, Türk ordusundaki acı tecrübelerden sonra gerçekleştirilen atılımları incelediğini, Adalar Meselesi'nin yakın zamanda çözüleceğine olan inancını belirtmiş ve Türk-Romen dostluğunun altını çizmişti. Ayrıca Balkanlar'da bir barış için Türk-Yunan uzlaşmasını arzuladıklarını vurgulamıştı. Tasfir-i Efkâr, 22 Nisan 1914, No:1056, s.1-2; Tasfir-i Efkâr, 24 Nisan 1914, No:1058, s.3.

${ }^{19}$ İkdam, 5 Mayis Efrenci 1914, No:6179, s.4.

${ }^{20}$ Sabah, 28 Nisan Efrenci 1914, No:8840, s.2; Ikdam, 28 Nisan Efrenci 1914, No:6172, s.4; Tanin, 28 Nisan Efrenci 1914, No:1920, s.2; Tanin, 29 Nisan Efrenci 1914, No:1921, s.1; Sabah, 29 Nisan Efrenci 1914, No:8841, s.2; Ikdam, 29 Nisan Efrenci 1914, No:6173, s.4; Tasfir-i Efkâr, 29 Nisan 1914, No:1063, s.4.

${ }^{21}$ Sabah, 1 May1s Efrenci 1914, No:8843, s.2.

${ }^{22}$ Tanin, 5 May1s Efrenci 1914, No:1927, s.1; Tanin, 6 May1s Efrenci 1914, No:1928, s.1.

${ }^{23}$ Livadia gezisi hakkında bakınız: Akdes N. Kurat. (2011). Türkiye ve Rusya, XVIII. Yüzyıl Sonundan Kurtuluş Savaşına Kadar Türk-Rus Illişkileri (1798-1919). TTK Yayınları, Ankara, s.216-224; Sabahattin Özel. (1998). Balkan ve Birinci Dünya Savaşları Arasındaki Dönemde Osmanlı Devleti Rusya İlişkileri. İstanbul Üniversitesi Edebiyat Fakültesi Güney-Doğu Avrupa Araştırmaları Dergisi, Say1:12, s.246,253; Kader Yılları, S. Sazonov'un Anıları-Rusya Eski Dışişleri Bakanı (1910-1916). (2002). Çev.: Betil Önuçak, Haz.: Sabahattin Özel, Derin Yayınları, İstanbul, s.155-163. Türk öğrencilerin gezisine katılmış olan Hüsnü Şermi’nin İstanbul'a dönmediği ve Talat Bey'in karşılanması sırasında Romanya'da bulunduğu anlaşılmaktadır. Dolayısıyla Talat Bey'in Romanya seyahatini, Tasfir-i Efkâr adına Hüsnü Şermi Bey izlemişti. Romanya gazetelerinin haberlerini aktarırken Talat Bey'in Ertuğrul (gemisi) ile Livadia'dan Romanya'ya gelmesinin planlandığını fakat Kral Carol'un Tuna ziyaretleri nedeniyle bu programın ertelendiğini belirtmişti. Tasfir-i Efkâr, 27 Mayıs 1914, No:1091, s.2. Talat Bey, Rus Çarı ile aralarında geçen bir konuşmayı, Romanya’ya giderken vapurda beraberindekilere anlatmıştı. Sabah adına geziyi takip eden Enis Bey (Enis Tahsin Til), Talat Bey’in aktardığı bu diyaloglara anılarında yer vermişti. Enis T. Til. (2004). Gazeteler ve Gazeteciler. Haz. İbrahim Şahin, Bilge Yayınları, Ankara, s.44-45.
} 
doğrudan İstanbul'a döneceğini haber yapmışlard $1^{24}$. Bu haberlerden sekiz gün sonra İkdam, gerçekleştirilecek Bükreş gezisinin programını ana hatlarıyla yayınlamıştı. Üstelik bu program, Talat Bey'in Romanya'ya gitmek üzere İstanbul'dan ayrılmasından bir hafta kadar önce gazetede çıkmıştı ${ }^{25}$. 20 Mayıs tarihli Tanin'de ise Bükreş kaynaklı haberlerden hareket edilerek Talat Bey'in 23 Mayıs'ta oraya gideceği ve yine bu gezinin Romanyalı yetkililerin gezisine karşıllk olduğu hakkında haberlere yer verilmişti ${ }^{26}$. Bu haberlere uygun şekilde Türk ve Romen öğrencilerin karşılıklı gezilerinin sona erdiği bir dönemde hatta Darülfünun öğrencilerinin İstanbul'a dönüşünden tam bir gün sonra Talat Bey ve beraberindeki Dahiliye Nezareti Kalemi Mahsus Müdürü Hasan Fehmi ve Emniyet-i Umumiye Müdürü İsmail Canbulat Beylerden oluşan Türk heyeti, 23 Mayıs’ta Romanya vapuruyla İstanbul'dan ayrılacakt1 ${ }^{27}$.

Talat Bey'in Romanya gezisi, başladığı andan itibaren -bazen Romanya kaynaklı haberlere de dayanarak- Türk basınının temel konularından biri haline gelecekti. Hatta M.S. imzalı (Mahmut Sadık olmalı) yazıda da belirtildiği üzere gazeteler "Hergün nazır-ı muhteremin Bükreş'de nasıl vakit geçirmiş olduğunu saati saatine gösteren telgraflar mektublar neşretti”' ${ }^{28}$. Gerçekten de gazetelerde Talat Bey ve Türk heyetinin Romanya' da kral, başbakan ve bakanlarla temasları üzerinde yoğun bir şekilde durulmuştu. Dolayısıyla Türk basınının yakından ilgilendiği ve hakkında çeşitli yorumlara yöneldiği bu yolculuk ${ }^{29}$

${ }^{24}$ Tanin, 10 Mayıs Efrenci 1914, No:1932, s.1; İkdam, 10 Mayıs Efrenci 1914, No:6184, s.2. O günlerde Sabah da Kral Carol'un gezisi nedeniyle Talat Bey’in Livadia'dan Bükreş'e doğrudan gitmekten vazgeçtiği hakkında bazı değerlendirmeleri sütunlarına taşımıştı. Sabah, 10 Mayıs Efrenci 1914, No:8852, s.2. Frankfurt Zeitung gazetesi, Livadia gezisini siyasi bir hamle olarak yorumlamıştı. Gazete, Çar ve Çariçe tarafından kabul edilmiş biri olarak Talat Bey'in Livadia'dan sonra Romanya'ya gitmesinin onun elini güçlendireceğini değerlendirmişti. Bu yorumda, Rusya gezisinin ardından Talat Bey'in Romanya'ya gerçekleştireceği ve Balkan sorunlarının ele alınacağı ziyaret sırasında artık daha önemli bir etkiye sahip olacağı ileri sürülmüştü. Halil E. Avcı. (2010). I. Dünya Savaşı Öncesinde Türk Hükümeti'nin Rus Baskısını Azaltma Girişimleri: Türk-Rus Komitesi’nin Kurulması ve Talat Bey’in Livadya Gezisi. Istanbul Üniversitesi Edebiyat Fakültesi Güney-Doğu Avrupa Araştırmaları Dergisi, Say1:18, s.105.

${ }^{25}$ İkdam, 18 Mayıs Efrenci 1914, No:6192, s.3. Nitekim Sabah hemen gezi öncesinde ana hatları çizilmiş kısa bir program yayınlamıştı. Bu programda Romanya Dışişleri Bakanı'nın ziyafeti, Kral Carol'un Talat Bey'i kabulü ve bazı ziyaretler yer alıyordu. Sabah, 22 Mayıs Efrenci 1914, No:8864, s.2. Romanya basınına göre, oradaki siyasi çevreler, bu geziye ciddiyetle yaklaşıyorlardı. İkdam, 11 Mayıs Efrenci 1914, No:6185, s.2. Dolayısıyla ilerleyen günlerde gazetelerde Talat Bey’in Livadia gezisini de kapsayacak çeşitli yorumlar yapılacaktı. İkdam, 19 Mayıs Efrenci 1914, No:6193, s.3. Bu arada bazı basın organları, bu gezinin resmi bir niteliğe sahip olmadığını ileri sürmüş̧tü. Ikdam, 20 Mayıs Efrenci 1914, No:6194, s.2. Gezinin tamamlandığı günlerde Tanin gazetesi ziyaretin resmi niteliği bulunmamasına rağmen "politika üzerinde tesiri görüleceğinde şüphe yoktur" diye yazacaktı. Tanin, 29 Mayıs Efrenci 1914, No:1951, s.1.

${ }^{26}$ Tanin, 20 May1s Efrenci 1914, No:1942, s.1.

${ }^{27}$ Gazetelerde heyetin yola çıkışı münasebetiyle gerçekleştirilen tören hakkında detaylar anlatılmış ve gezinin programı üstünde durulmuştu. Öte yandan Talat Bey'in gezinin amacının Tache Ionescu'ya iadeyi ziyaret olduğu yönündeki açıklamasına da yer verilmişti. İkdam, 23 Mayıs Efrenci 1914, No:6197, s.2; İkdam, 24 Mayıs Efrenci 1914, No:6198, s.2; Tanin, 24 Mayıs Efrenci 1914, No:1946, s.1; Sabah, 24 Mayıs Efrenci 1914, No:8866, s.1.

${ }^{28}$ M.S.(Mahmut Sadı), "Romanya'dan Gelirken”, Sabah, 29 Mayıs Efrenci 1914, No:8871, s.1. Enis Tahsin ise anılarında "Talat Beyin Bükreş’te kaldı̆̆ günlerde, kendisini adım adım takip ettik; ziyaretlerini, kimlerle görüştügünü gazetelere bildirdik. Talat Bey Türk gazetelerini arkasında görmekten adeta memnun oluyordu. Nafia nezareti[ni] ziyaret ettiği gün bizi de beraber Nazırın yanına çıkardı, bir nezaket ziyareti olan bu görüşmede bizler de bulunduk" diyordu. Til, a.g.e., s.44.

${ }^{29}$ Sabah gazetesi Enis Bey (Enis Tahsin Til) aracılı̆̆ 1 ile geziyi takip etmişti. Nitekim Enis Bey, Romanya vapurunun Karadeniz'e açılması ve fırtınalı bir havada yolculuğun geçtiği haberleriyle birlikte süreci başından itibaren İstanbul'a aktarmaya başlayacaktı. Enis Tahsin, yer yer şehri detaylı şekilde anlatmaya çalışmıştı. Sabah, 25 Mayıs Efrenci 1914, No:8867, s.1,3; Enis Tahsin, "Bükreş Yolunda”, Sabah, 27 Mayıs Efrenci 1914, No:8869, s.1-2; Enis Tahsin, "Bükreş'de Son Günler”, Sabah, 30 Mayıs Efrenci 1914, No:8872, s.1; Til, a.g.e., s.43-44. Tasfir-i Efkâr da geziye odaklanan gazeteler arasındaydı. Yunus Nadi, 25 Mayıs'ta kaleme aldığı yazısında Romanya ile Yunanistan ilişkilerinin kötüye gittiğini bundan dolayı Romanyalıların Türklerle ilişkilerine önem verdiklerini değerlendirmişti. Yunus Nadi, "Siyaset-Yunanistan-Romanya Münasebetleri”, Tasfir-i Efkâr, 25 Mayıs 1914, No:1089, s.1. Gazete 29 Mayıs baskısının birinci sayfasının tümünü, ikinci sayfasının önemli bir 
kamuoyunun gündemine devletler düzeyindeki Türk-Romen ilișkilerini tașıyacakt1 ${ }^{30}$. Nitekim 23 Mayıs'ta başlayan gezi dolayısıyla Sabah gazetesinde Türk-Romen ilişkilerini politik, ekonomik ve Balkanların şartları açısından değerlendiren bir yazı kaleme alınmıştı. Yine M.S. imzalı bu makalede iki ülke dostluğunun göstergelerinden biri olarak öğrenci gezilerinin altı çizilmişti๋ ${ }^{31}$. Bedri Kamil de Osmanlı Darülfünun öğrencilerinin gezilerinin tamamlandığ bir sırada Talat Bey'in ziyaretinin başlamasını iki ülke arasındaki ilişkilerin samimiyeti açısından bir gösterge olarak ele almışt1 ${ }^{32}$. İkdam da öğrenci temaslarına dostluk açısından bir gösterge olarak yaklaşmış gezinin Tache Ionescu ile Coanda'nın ziyaretlerine karşılık olduğunu hatırlatmış; bunların yanında siyasi açıdan önemini de vurgulamışt ${ }^{33}$.

Talat Bey ve beraberindekiler ise 24 Mayıs'ta Köstence'ye ulaştıklarında Romanyalı yetkililerce karşılanmışlard ${ }^{34}$. Aynı gün Türk heyeti çeşitli ziyaretlerde bulunarak şehrin görülmesi gereken mahal ya da mevkilerini gezmişti. Bunların yanında Bükreş treni beklenirken vapurda çay ziyafeti düzenlenmişti ${ }^{35}$. Heyet, buradaki temaslarından sonra özel trenle Bükreş'e geçmişti. Talat Bey ve beraberindekiler, Romanya'nın başkentinde Kral Carol'un yaveri, bakanlar ve Osmanlı Sefiri Safa Bey tarafından törenle karşılanmışlardı. Bükreş’teki ilk gününde Talat Bey, Kral Carol tarafindan huzura kabul edilmişti. Yine o gün çeşitli ziyaretler gerçekleştiren Türk heyeti, at yarışı gibi etkinliklere de katılmışt1 ${ }^{36}$.

kısmını ve dördüncü sayfasının ise yarısını bu konuya ayırmıştı. Tasfir-i Efkâr, 29 Mayıs 1914, No:1093, s.1,2,4. Talat Bey yola çıkmadan bir gün önce Darülfünun öğrencilerinin Romanya'dan döndüklerini hatırlatan İkdam da gezi ile yakından ilgilenmişti. İkdam, 24 Mayıs Efrenci 1914, No:6198, s.1,2. Enis Tahsin'in aktardığına göre geziyi takip eden gazeteciler Jöntürk adına Zaven Efendi ve Tanin adına Falih Rıfkı idi. Enis Tahsin, "Bükreş Yolunda", Sabah, 27 Mayıs Efrenci 1914, No:8869, s.1; Til, a.g.e., s.43-44. Tanin muhabiri, 27 Mayıs'ta yayınlanan yazısında Köstence'ye gemi yolculuğunu anlatırken gemide bulunan Washington Sefiri Ahmet Rüstem Bey ile yaptığı kısa görüşmeye yer vermişti. Siyasi temas ve gelişmelerin yanında gezileriyle Bükreş'i ve mekanlarını tanıtan hatta biraz portreleştiren yazılar göndermişti. Tanin, 27 Mayıs Efrenci 1914, No:1949, s.1; Tanin, 28 May1s Efrenci 1914, No:1950, s.1-2; Tanin, 29 May1s Efrenci 1914, No:1951, s.1-2.

${ }^{30}$ Bununla birlikte özellikle Avrupa basınında iki ülkenin yakınlaşması, Adalar Sorunu gibi detayları kapsayacak şekilde Türk-Yunan münasebetleriyle ilişkilendirilmişti. "Osmanl1-Romen Münasebeti”, Sabah, 6 Mayıs Efrenci 1914, No:8848, s.1; Sabah, 14 Mayıs Efrenci 1914, No:8856, s.1. Romanya’daki siyasi çevreler ise Talat Bey yola çıkmadan önce bu geziyi, Türk-Yunan sorunları, Türk-Bulgar ilişkileri ve Balkanların durumu gibi konular bağlamında ele almışlardı. Tasfir-i Efkâr, 19 Mayıs 1914, No:1083, s.2.

${ }^{31}$ M.S., "Romanya’ya Giderken: Seyahat Münasebetiyle”, Sabah, 23 May1s Efrenci 1914, No:8865, s.1.

${ }^{32}$ Bedri Kamil, "Romanya ve Romenler", Sabah, 25 Mayıs Efrenci 1914, No:8867, s.3.

33 "Romanya Seyahati”, İkdam, 24 Mayıs Efrenci 1914, No:6198, s.1.

${ }^{34}$ Geziyi takip eden ve zaten Romanya'da bulunan Hüsnü Şermi, Talat Bey ve yanındakiler Köstence’ye ulaşmadan önce şehrin tanınmış kahvelerinden Bristol'de (?) Romanya Emniyet-i Umumi Müdürü adına Talat Bey’i karşılamaya gelen Konstan (?) isimli yetkili ile buluşarak gezi programını öğrenmişti. Gazetede yayınlanan programa göre Pazar sabahı Köstence'ye varış sonrasında Bükreş’e trenle yola çıkılacak, Bükreş’te otelde bir süre dinlenildikten sonra Saray’da resmikabul gerçekleşecek ve ziyafet düzenlenecekti. Pazartesi, Sefir Safa Bey’in ziyafeti ve akşam Hariciye Nazırı'nın resmi ziyafeti gerçekleştirilecekti. Salı günü Talat Bey, çeşitli ziyaretlerden sonra akşam Tache Ionescu'nun ziyafetine katılacaktı. Çarşamba programında ziyaretlerin yanında şehir gezisi ve akşam yine bir ziyafet vardı. Perşembe günü Köstence'ye dönülecekti. Tasfir-i Efkâr, 27 Mayıs 1914, No:1091, s.2.

${ }^{35}$ Birçok gazete çay ziyafetini Talat Bey’in düzenlediğini yazarken Enis Tahsin, Köstence Mutasarrıflığı/Romanya Hükümeti’nce düzenlendiğini aktarmıştı.

3625 Mayıs tarihli Sabah, at yarışı sırasında Talat Bey'in, General Coanda ile görüşme firsatı bulduğunu ve İtalya'nın Bükreş Sefarethanesi'nde Talat Bey şerefine bir organizasyon düzenlendiğini yazmıştı. Aynı haberler diğer gazetelerden de büyük ölçüde izlenebilmektedir. Tasfir-i Efkâr, 25 Mayıs 1914, No:1089, s.4; Tanin, 25 Mayıs Efrenci 1914, No:1947, s.4; Sabah, 25 Mayıs Efrenci 1914, No:8867, s.1,3; Sabah, 26 Mayıs Efrenci 1914, No:8868, s.2,3; Enis Tahsin, "Bükreş Yolunda”, Sabah, 27 Mayıs Efrenci 1914, No:8869, s.1-2; Tasfir-i Efkâr, 27 Mayıs 1914, No:1091, s.2; Tanin, 27 Mayıs Efrenci 1914, No:1949, s.1; Tanin, 28 May1s Efrenci 1914, No:1950, s.1-2; Hüsnü Şermi, "Romanya Mektubu", Tasfir-i Efkâr, 28 Mayıs 1914, No:1092, s.3. Özellikle Tanin, İtalya Sefarethanesi ve buradaki organizasyon hakkında bilgi vermektedir. Sabah ve Tanin'de Romanya Ermenilerinin Talat Bey ile temasa geçtikleri ve hoş geldiniz ziyaretinde bulundukları vurgulanmıştı. İkdam ise karşılama 
Kral Carol ile görüșmesinden sonra Enis Tahsin Bey tarafindan "saraydan çıkdıkları zaman pek memnun ve beşûş̧ görünüyorlard "” ${ }^{37}$ cümlesiyle tanımlanan Talat Bey, 25, 26 ve 27 Mayıs'ta temaslarını sürdürmüş; Romanya Başvekili Ion I. C. Bratianu, Hariciye Nazırı Porumbaru ve Tache Ionescu gibi isimlerle bir araya gelmiş; şerefine düzenlenen ziyafetlere katılmıştı ${ }^{38}$. Tanin'in yayınladığ1 27 Mayıs tarihli telgraftaki "Bir Tayran-Ziyaretler ve Ziyafetler" başlığı gezinin -gerçekte sadece bir kısmı için kullanılmış olsa da- önemli bir bölümünü tanımlamaktayd ${ }^{39}$. Sinaya'ya giden ve çeşitli mekanları gezen Talat Bey ve beraberindekiler, Bükreş'e döndükten sonra 28 Mayıs akşamı Bratianu, Tache Ionescu ve General Coanda gibi bir çok ileri gelenin katıldığı bir törenle Köstence'ye uğurlanmışlardı. Yine düzenlenen tören eşliğinde, 29 Mayıs'ta İstanbul'da olacak şekilde Köstence'den yola çıkmışlard1 ${ }^{40}$. Talat Bey, İstanbul'a döndükten sonra padişaha temasları hakkında bilgi vermiş ve sadrazamla değerlendirmelerde bulunmuşstu ${ }^{41}$.

haberlerinin yanı sıra 24 Mayıs akşamı Tache Ionescu'nun Talat Bey şerefine bir ziyafet düzenlediğini haber yapacaktı. Ikdam, 26 Mayıs Efrenci 1914, No:6200, s.3.

${ }^{37}$ Enis Tahsin, “Bükreş’te İki Gün”, Sabah, 28 Mayıs Efrenci 1914, No:8870, s.1.

38 Tasfir-i Efkâr' ’n muhabiri Hüsnü Bey, Talat Bey şerefine 25 Mayıs günü öğle vakitlerinde Dahiliye Nezareti'nde, akşam ise Hariciye Nezareti'nde ziyafet düzenlendiğini, gün içinde Talat Bey'in iade-i ziyaretleri kabul ettiğini ve şehri gezdiğini aktarmıştı. Tasfir-i Efkâr, 26 Mayıs 1914, No:1090, s.1,5. İkdam, 26 Mayıs tarihli haberlere dayanarak Talat Bey’in Romanya Başvekili Ion I.C. Bratianu'dan sonra Nafia Nezareti'ni ziyaret ettiğini ve Romanya Hariciye Nazırı Emanuel Porumbaru ile özel olarak görüştüğünü aktarmıştı. Ayrıca eski Dahiliye Nazırı Tache Ionescu'nun büyük bir ziyafet düzenlediğini yazmıştı. İkdam, 27 Mayıs Efrenci 1914, No:6201, s.3. Sabah muhabiri Enis Tahsin ise 12 Mayıs'ta (25 Mayıs) akşam 8'de çektiği telgrafta Talat Bey'in Bratianu, Vasile G. Mortun (Dahiliye Nazırı) ve Porumbaru ile ziyaret ya da ziyafet gibi çeşitli vesilelerle temas kurduğunu aktarmıştı. Gün boyunca nezaret ziyaretleri ve farklı organizasyonlar sürecekti. 13 Mayıs (26 Mayıs) tarihli telgrafında bir önceki gece Porumbaru tarafından verilen ziyafetle Fransız Sefarethanesi'ndeki müsamere üzerinde durmuştu. 23 Mayıs [yine 13 Mayıs olmalı] sabah saat 11 olarak yayınlanan başka bir telgrafta Tache İonescu'nun ziyafeti, Sefarethane'de balo (aynı gün), Saray’da ziyafet (ertesi gün-Çarşamba), Sinaya gezisi (Perşembe) olmak üzere sonraki sürecin programını aktarmıştı. Sabah, 27 Mayıs Efrenci 1914, No:8869, s.1,3. Sonraki telgraflarında Fransız Sefarethanesi'ndeki müsamere ile Tayyare Meydanı ziyareti üzerinde durmuştu. Sabah, 28 Mayıs Efrenci 1914, No:8870, s.1. Enis Tahsin telgrafları dışında mektuplarıyla detaylı bir şekilde Bükreş’i, temasları ve yaşananları aktarmıştı. Enis Tahsin, "Bükreş Yolunda”, Sabah, 27 Mayıs Efrenci 1914, No:8869, s.1-2; Enis Tahsin, "Bükreş’te İki Gün”, Sabah, 28 Mayıs Efrenci 1914, No:8870, s.1-2; Enis Tahsin, "Bükreş Müessesatını Ziyaret”, Sabah, 29 Mayıs Efrenci 1914, No:8871, s.1; Enis Tahsin, "Bükreş'de Son Günler”, Sabah, 30 Mayıs Efrenci 1914, No:8872, s.1. 27 Mayıs tarihli Tasfir-i Efkâr da Talat Bey'in 26 Mayıs’ta Romanya Başvekili ile iki saat görüştüğünü haber yapmıştı. Tasfir-i Efkâr, 27 Mayıs 1914, No:1091, s.4. Diğer gazeteler gibi Türk heyetin Bükreş’teki temas ve gezilerini haber yapan Tanin, Romanya Polis Müdür-i Umumisi'nin İsmail Canbolat Bey şerefine bir ziyafet verdiğini aktarmaktadır. Tanin, 27 Mayıs Efrenci 1914, No:1949, s.4.

39 Telgrafta Talat Bey'in Romanya tayyareciliği ile ilgilendiği, Tayyare Mektebi ile Tayyare Hangarları'nı gezdiğini ve uçuş yaptığını aktarmıştı. Ayrıca Tache Ionescu'nun bir ziyafet verdiği, sonra resmikabul düzenlendiği ve 27 Mayıs'ta Türk misafirler şerefine Saray’da büyük bir ziyafet hazırlandığı belirtilmişti. Tanin, 28 May1s Efrenci 1914, No:1950, s.1. Tanin bir sonraki gün yine Saray'daki ziyafet, Sefaret'teki resmikabul ve Talat Bey'in Sinaya'ya gidişiyle ilgili telgrafları yayınlamıştı. Tanin, 29 Mayıs Efrenci 1914, No:1951, s.1,3. Saraydaki ziyafet Sabah'a da konu olmuştu. Sabah, 28 Mayıs Efrenci 1914, No:8870, s.3; Sabah, 29 Mayıs Efrenci 1914, No:8871, s.1. Tasfir-i Efkâr, 27 Mayıs'ta Saray'da ziyafet düzenlendiğini, Talat Bey'in Dahiliye Nezareti ile Emniyet-i Umumiye Müdüriyeti'ni ziyaret ettiğini belirtmektedir. Tayyare Mektebi ile hangarların ziyareti ise 27 Mayıs tarihli telgrafta geçmektedir. Tasfir-i Efkâr, 28 Mayıs 1914, No:1092, s.3-4. İkdam ise ziyafetleri (Tache Ionescu ile Sefir Safa Bey'in düzenledikleri ziyafetlerle sefaretteki ziyafet ve balo) 27 Mayıs ile tarihlendirirken Tayyare Mektebi ve hangarların gezilmesi, şehrin üstünde uçulması ve Saray’da verilen öğle ziyafetini, 26 Mayıs olarak tarihlendirmişti. Ayrıca 27 Mayıs'ta Kral Carol tarafından bir ziyafet verildiği haberi gazetede yer almıştı. İkdam, 28 Mayıs Efrenci 1914, No:6202, s.2. 29 Mayıs tarihli Ikdam'a göre Talat Bey, 27 Mayıs'ta Romanya Başvekili'nden başka Avusturya-Macaristan sefiri ile görüşmüştü. İkdam, 29 Mayıs Efrenci 1914, No:6203, s.3. Tanin ve Sabah da aynı bilgiyi aktarmaktadır. Tanin, 29 Mayıs Efrenci 1914, No:1951, s.1; Sabah, 29 Mayıs Efrenci 1914, No:8871, s.1.

${ }^{40}$ İkdam, 29 Mayıs Efrenci 1914, No:6203, s.5; Sabah, 29 May1s Efrenci 1914, No:8871, s.1; Enis Tahsin, “Bükreş'de Son Günler”, Sabah, 30 Mayıs Efrenci 1914, No:8872, s.1.

${ }^{41}$ İkdam, 31 May1s Efrenci 1914, No:6205, s.1. 
İki ülke arasındaki bu yakınlaşma sürecinin paralelinde, Talat Bey'in İstanbul'a döndügü günlerde (29 Mayıs 1914) ${ }^{42}$, ilk kez 1911 yılında ortaya çıkan Türkiye-Romanya Ticaret Muahedesi'nin görüşmelerine yeniden başlanılacağı haberleri gazete sütunlarına taşınmışt ${ }^{43}$. Haziran başlarında ise gazete sütunlarını işgal eden konulardan biri Romanya Veliahtı'nın İstanbul'a geliş tarihi olacakt ${ }^{44}$. Ancak Haziran ortalarına gelindiğinde, bu gezinin ertelendiği haberleri gazetelerde çıkmış $\mathrm{t}^{45}$.

Siyaset ve basın çevreleri kadar Talat Bey'in kendisinin de Romanya'daki temaslarından ve bu ülkenin barışçı politikasından memnuniyet duyduğu anlaşılmaktadır ${ }^{46}$. Nitekim Tanin'in muhabiriyle 28 Mayıs'ta Bükreş'te yaptığı röportajda iki ülkeyi ilgilendiren konularda Romen devlet adamlarıyla müşterek düşündüklerini belirterek "... bu mülakatlardan sonra hükümeteyn arasında daimi bir dostluk tesis etmiş olacaktır" diyecekti ${ }^{47}$. Öte yandan Porumbaru, Tache Ionescu gibi Romanyalı siyasiler ve birçok akademisyen ya da ileri gelen, Balkanlarda barış ve iki ülkenin ilişkilerinin gelişmesi açısından Talat Bey'in gezisini önemli bir gelişme olarak yorumlamışlard1 ${ }^{48}$. Temasların yoğunluğunu göz önüne alan Hüsnü Şermi ise bu gezinin eski bir nazıra iadeyi ziyaretten öte "ziyaret-i mühimme-i siyasiye" halini aldığını ifade etmekten geri durmayacaktı. Zaten Romanya diplomasi çevrelerince Türk-Romen ilişkilerinin geliştirilmesi açısından bu ziyaretin değeri analiz edilirken Romanya basını da Türk-Romen ittifakını çok güçlü bir ihtimal olarak ele almaya başlayacaktı ${ }^{49}$. Bu arada Talat Bey'in tamamlanan ziyareti, 29 Mayıs'ta Adevarul ve 31 Mayıs'ta Epoka gazetelerince yorumlanacaktı ki bu gazetelerin yazıları Osmanlı cephesinde de dikkat çekecekti ${ }^{50}$.

Basın düzleminden yaklaşıldığında gerek yayın organlarının analiz ya da yorumları gerekse gazetelerde çıkan haberler, Talat Bey'in gezisinin olumlu sonuçlar doğurduğuna işaret etmektedir. Gezinin ilk gününde Osmanlı heyetinin Bükreș’te coşkulu bir șekilde karşılanmasını vurgulayan Tasfir-i Efkar ${ }^{51}$, Romanya'nın diğer Balkan devletlerine göre Osmanlı Devleti'ne karşı daha farklı ve dostça yaklaştığını, bu politikanın -bazı istenmeyen ve dönemin şartlarıyla ilgili diyaloglar bir kenara bırakılması koşuluyla- Balkan Savaşları sürecinde de sergilendiğini değerlendirmişti ${ }^{52}$. Hüsnü Şermi, Talat Bey'in gezisi sırasında Romanya basınının Türk-Romen itilaf ve ittifakından bahsettiğini, hatta bu yönde bir beklenti olduğunu aktarmişt1 ${ }^{53}$.

Romanya basınından alıntı yapan İkdam, bir gazetenin ${ }^{54}$ yorumuna özel yer ayırmıştı. Gazete Osmanlı'nın Balkan Savaşı'ndan sonra yaralarını sarması ve konumunu güçlendirmesi

\footnotetext{
42 İkdam, 30 Mayıs Efrenci 1914, No:6204, s.1,2,3; Tasfir-i Efkâr, 30 Mayıs 1914, No:1094, s.1,2; Tanin, 30 Mayıs Efrenci 1914, No:1952, s.1,2.

${ }^{43}$ İkdam, 28 May1s Efrenci 1914, No:6202, s.2.

${ }^{44}$ Sabah, 4 Haziran Efrenci 1914, No:8877, s.3; Sabah, 5 Haziran Efrenci 1914, No:8878, s.2; Tanin, 5 Haziran Efrenci 1914, No:1958, s.1; Sabah, 6 Haziran Efrenci 1914, No:8879, s.2; İkdam, 6 Haziran Efrenci 1914, No:6211, s.2; Ikdam, 7 Haziran Efrenci 1914, No:6212, s.2; Tanin, 7 Haziran Efrenci 1914, No:1960, s.1.

45 Sabah, 14 Haziran Efrenci 1914, No:8887, s.3.

${ }^{46}$ Sabah, 28 Mayıs Efrenci 1914, No:8870, s.3; Tasfir-i Efkâr, 28 Mayıs 1914, No:1092, s.4; İkdam, 29 Mayıs Efrenci 1914, No:6203, s.3; Sabah, 29 Mayıs Efrenci 1914, No:8871, s.1.

${ }^{47}$ Tanin, 29 May1s Efrenci 1914, No:1951, s.1.

${ }^{48}$ Sabah, 30 Mayıs Efrenci 1914, No:8872, s.1; Enis Tahsin, “Talat Bey'in Seyahati”, Sabah, 31 May1s Efrenci 1914, No:8873, s.1.

${ }^{49}$ Hüsnü Şermi, "Romanya Mektubu", Tasfir-i Efkâr, 28 Mayıs 1914, No:1092, s.3. Aynı yaklaşımı Enis Tahsin de sergilemişti. Enis Tahsin, “Talat Bey’in Seyahati”, Sabah, 31 Mayıs Efrenci 1914, No:8873, s.1.

${ }^{50}$ Ayrıntı için bkz.: BOA, DH.KMS, Dosya No:63, Gömlek No:64.

${ }^{51}$ Tasfir-i Efkâr, 25 Mayıs 1914, No:1089, s.4.

${ }^{5}$ Tasfir-i Efkâr, 26 Mayıs 1914, No:1090, s.1. Aynı yaklaşımı İkdam da sergilemişti. "Romanya Seyahati”, İkdam, 24 Mayıs Efrenci 1914, No:6198, s.1.

${ }^{53}$ Hüsnü Şermi, bu yoğun görüşme ya da ziyafet trafiğini dahil olan isimleri de sıralayarak aktarmaya çalışmıştı. Tasfir-i Efkâr, 28 Mayıs 1914, No:1092, s.2.

${ }^{54}$ Indepandans Romen (Independence Romen) (?).
} 
gerektiğini; bu durumun ise iki devletin dostluğunu kolaylaştırdığını savunmuş ve güçlenen bir Osmanlı'nın Boğazların güvenliği açısından önemli olduğunu belirtmişti ${ }^{55}$. Boğazların yanı sıra Doğu Avrupa ve Balkanlar için önemli denge unsuru durumundaki Osmanlı'nın zaafa uğramasının Romanya'yı etkileyeceğini ileri süren gazete "Adalar meselesi, Osmanlı politikasında siyah bir nokta teşkil ediyor" ifadesinden sonra Türk-Yunan uzlaşmasının zorunluluğunu vurgulayacaktı. Ayrıca gazetede Balkanlar' da barış ve istikrar vurgusuna ihtiyaç duyulmuştu ${ }^{56}$.

\section{Savaşın İlk Günlerinde Talat Bey'in İkinci Romanya Gezisi}

Balkan devletlerinin Balkan Savaşları'ndan kalan sorunlara bağlı olarak kamplaştığı bir süreçte Avusturya-Macaristan İmparatorluğu Veliahdı'na Saraybosna'da suikast düzenlenmesi, Balkanlarda dengeleri yeniden şekillendirmişti. Bu suikastin uzantısı olarak Birinci Dünya Savaşı'nın başlaması ise Balkan devletlerini milliyetçi hedeflere yöneltecekti. Böyle bir ortamda, 2 Ağustos 1914'te Almanya ile gizli bir ittifak kuran ve aynı gün seferberlik ilan eden Osmanlı Hükümeti, Balkan devletlerinin alacağı pozisyonlardan etkileneceğini düşündüğünden Romanya ve Bulgaristan ile ittifak arayışına girişmiştir ${ }^{57}$.

Birinci Dünya Savaşı'nın başladığı dönemde Romanya, birkaç açıdan Türk kamuoyunun gündemine gelmişti. Öncelikle Tercüman-ı Hakikat gazetesinin ifadeleriyle Birinci Dünya Savaşı'nın başlangıcını ifade eden Ağustos'un ilk günlerinde Romanya'da "büyük bir galeyan ve heyecan hükümfermadır... Meclis-i Nuzzar bu gün [3 Ağustos] Sinaya'da inikad etmiş ve ruznameye dahil mesail ile Romanya'nın ittihaz edeceği tarz-ı hareket hakkında müzakeratta bulunmuştur." 58 Öte yandan basın Romanya’yı savaşa yönelik bir hazırlık yapıp

\footnotetext{
${ }^{55}$ İkdam, 28 Mayıs Efrenci 1914, No:6202, s.2. Diğer gazetelerde de bu yoruma yer verilmişti. Tanin, 29 Mayıs Efrenci 1914, No:1951, s.1; Sabah, 29 Mayıs Efrenci 1914, No:8871, s.1. Tache İonescu da Boğazlarda güçlü bir Türkiye'nin Romanya'nın menfaatine olduğunu açıklamıştı. Sabah, 30 Mayıs Efrenci 1914, No:8872, s.3.

${ }^{56}$ İkdam, 29 Mayıs Efrenci 1914, No:6203, s.3. Bu geziye önem veren Paris basını, gezideki temasları, Osmanl1Yunan anlaşmazlığını ortadan kaldırma çabaları ile ilişkilendirmişti. İkdam, 31 Mayıs Efrenci 1914, No:6205, s.1; Tasfir-i Efkâr, 31 Mayıs 1914, No:1095, s.1. Talat Bey hakkında çok olumlu değerlendirmeler yapan Romanya basını ise görüşmeler sırasında Türk-Yunan ilişkileri ile Adalar Meselesi'nin gündeme geleceği üzerinde durmuştu. Enis Tahsin, “Bükreş’te İki Gün”, Sabah, 28 Mayıs Efrenci 1914, No:8870, s.1. Enis Tahsin'e göre Adalar Meselesi konuşulmamıştı. Enis Tahsin, “Talat Bey’in Seyahati”, Sabah, 31 Mayıs Efrenci 1914, No:8873, s.1. Fakat bu meselenin çözümü aşamasında Kral Carol'un hakemliği üzerinde durulduğu yönünde haberler gazetelere yansımıştı. İkdam, 31 Mayıs Efrenci 1914, No:6205, s.1; Tasfir-i Efkâr, 31 Mayıs 1914, No:1095, s.1. Ziyaretinden duyduğu memnuniyetini İstanbul'a ulaştığında verdiği demeçle ortaya koyan Talat Paşa, Adalar Meselesi'nin doğrudan doğruya Romanya ile ilgili olmadığını belirtmişti. Buna rağmen meselenin barışçı yollarla ve bir uzlaşma ile sonuçlanmasını isteyen Romanya’nın, bu yönde bir politik yaklaşıma sahip olduğunu açıklamıştı. Sabah, 30 Mayıs Efrenci 1914, No:8872, s.1; Tasfir-i Efkâr, 30 Mayıs 1914, No:1094, s.2; Tanin, 30 Mayıs Efrenci 1914, No:1952, s.1. Talat Bey, Adalar Meselesi'nin barışçı yöntemle çözümünde Romanya'nın aracılığının etkili olabileceğini söylerken Carol'un hakemliğinin kabul edildiği haberini yalanlamıştı. İkdam, 2 Haziran Efrenci 1914, No:6207, s.1.

57 Özçelik, a.g.m., s.262-263; Hasan Babacan. (2012). Mehmed Talât Paşa 1874-1921. Altınpost Yayıncılık, Ankara, s.122-123.

${ }^{58}$ Tercüman-ı Hakikat, 3 Ağustos Efrenci 1914, No:11965, s.2. Birinci Dünya Savaşı öncesinde Romanya'nın iki temel davası vardı. Bunlar Transilvanya ve Besarabya'nın sınırlarına katılması isteğiydi. Yusuf H. Bayur. (1991). Türk Inkılâbı Tarihi. c.II/IV, TTK Yayınları, Ankara, s.524-525; Yusuf H. Bayur. (1991). Türk Inkılâbı Tarihi. c.III/I, TTK Yayınları, Ankara, s.109-110.
} 
yapmadığ $1^{59}$ ya da tarafsızlı̆̆ haberleriyle ele almışt1 ${ }^{60}$. Romanya'nın durumu ve şartları, Türk yazarların da öncelik verdiği konulardandı. 16 Ağustos'ta (yani Talat Bey'in BulgaristanRomanya ziyaretleri için İstanbul'dan ayrılışının ertesi günü) Tasfir-i Efkar, Romanya'nın önemine işaret eden bir yazı yayınlamıştı. Yazıda "Asıl büyük rolü Balkanlar Harbi esnasında ifa etmiş ve adeta bir aralı Balkanlılar arasında hakemlik ve hâkimlik vazifesini görmüştür. Şimdi ise Romanya'nın yalnız Balkanlarda değil, hatta Avrupa'nın hayat-ı umumiyesinde bile fevkalade mühim tesirler icra edecek hal ve mevki ihraz etmiş olduğunu kemal-i hayretle görüyoruz" ifadelerinden sonra Romanya'nın gerçekte sınırlı güçte bir devlet olduğunun altı çizilmiştit ${ }^{61}$.

Ahmet Agayef (A ğaoğlu) ise Romanya için taraf seçmenin güç olduğunu "Romanya bugün ateşle yağmur arasında kalmış birinin halindedir" cümlesiyle aktarırken ülkenin tarafsızlık çatısı altında beklediğini, zaman kazandığını ve herhangi bir tarafın tehlikesine maruz kalmak istemediğini savunmuştu. Halk ile Kral arasında savaş için seçilecek taraf/müttefik hakkında anlaşmazlık olduğu yönündeki görüntünün ise Romanya'nın oyalama taktiği olduğunu ileri sürmüştü. Yazara göre "Romanya da bu birkaç gün esnasında İttifakMüselles'i iltizam etmek tariki ile kendi vaziyetini tayin edecektir"62. Romanya'nın yaşadığ 1 ikilemi Yunus Nadi "Romanya'nın His ve Fikir Mübarezesi” başlıklı yazısıla kaleme almıştı. "Romanya'nın menfaati Ittifak-ı Müsellese aleyhdar olmakda değildir" diyen Yunus Nadi, Transilvanya'ya yönelik istekleriyle Romanya'nın tarafsı kalmasının güçlügünü karşılaştırmışt1 ${ }^{63}$. Romanya cephesi ise seferberlik ilan edilse de tarafsızlıklarını sürdürecekleri yönünde bildirimlerde bulunurken ${ }^{64}$ Tache Ionescu (Muhafazakâr Demokrat Firkası Reisi) Romanya gazetesine ne vaat edilirse edilsin şimdilik Romanya'nın tarafsız kalması gerektiğini açıklamışt1 ${ }^{65}$.

Yine Romanya vasıtasıyla -en azından bir kısım yayın organlarında- Balkan İttihadı fikrinin tartışıldığı bir dönemde ${ }^{66} 15$ Ağustos 1914'te Dâhiliye Nazırı Talat ile Meclis-i

\footnotetext{
${ }^{59}$ Tanin'de Ağustos'un ilk günlerinde Romanya'nın ihtiyatları silâhaltına almak ya da idare-i örfi ilan etmek gibi savaş hazırlıkları içinde bulunmadığı yer almıştı. Tanin, 2 Ağustos Efrenci 1914, No:2015, s.2. Tanin'in haberinden birkaç gün sonra Tasvir-i Efkâr, Romanya Hükümeti'nin Rusya ile olan sınırına asker yığarken seferberlik kararı verdiğini yazmıştı. Tasvir-i Efkâr, 6 Ağustos 1914, No:1160, s.2,4. Ancak seferberlik ilan edilmeden hazırlıklara başlanmıştı. Tasfir-i Efkâr, 7 Ağustos 1914, No:1161, s.2. Ayrıca Tasvir-i Efkâr, Kral Carol başkanlığında toplanan Heyet-i Vükela'nın sınırları korumak üzere tedbir alma kararı verdiğini aktarmıştı. Tasvir$i$ Efkâr, 5 Ağustos 1914, No:1159, s.4. Gazete haberlerine göre Romanya, Ekim sonlarında Amerika'dan 20.000.000 fișek satın alacaktı. Tanin, 30 Teşrin-i Evvel Efrenci 1914, No:2103, s.4.

${ }^{60}$ Tanin, 5 Ağustos Efrenci 1914, No:2018, s.4; Tercüman-ı Hakikat, 8 Ağustos Efrenci 1914, No:11970, s.1.

${ }^{61}$ Tasfir-i Efkâr, 16 Ağustos 1914, No:1170, s.1. Gazete, 18 Ağustos günü bu yazısını hatırlatan bir özet vermişti. Tasfir-i Efkâr, 18 Ağustos 1914, No:1172, s.1.

${ }^{62}$ Ahmet Agayef, "Siyasiyat-İtalya ve Romanya", Tercüman-ı Hakikat, 10 Ağustos Efrenci 1914, No:11972, s.1. Ahmet Agayef, 15 Ağustos tarihli yazısında Romanya'nın İttifak Devletleri'nin menfaatlerini gözeterek tarafsızlığını sürdürdüğünü ileri sürecekti. Ahmet Agayef, "Siyasiyat-İtalya ve Balkan Devletleri”, Tercüman-ı Hakikat, 15 Ağustos Efrenci 1914, No:11977, s.1.

${ }^{63}$ Yunus Nadi, "Siyasiyat-Romanya'da His ve Fikir Mübarezesi”, Tasfir-i Efkâr, 14 Ağustos 1914, No:1168, s.1. Yunus Nadi, Romanya'nın tarafsızlığına ve Balkanlarda bir ittifak anlayışına mesafeli yaklaşıyordu. Yunus Nadi, "Siyasiyat-Romanya'nın Vaziyeti Hakkında Mülakat”, Tasfir-i Efkâr, 20 Ağustos 1914, No:1174, s.1. Bazı yabancı yayın organları da Romanya'nın kendi isteği ya da zorla tarafsızlıktan ayrılırsa "Merkezi Düvel-i Muazzama'ya" yardım edeceğini ileri sürüyorlardı. Tasfir-i Efkâr, 12 Ağustos 1914, No:1166, s.4.

${ }^{64}$ Tasfir-i Efkâr, 9 Ağustos 1914, No:1163, s.4.

${ }^{65}$ Tercüman-ı Hakikat, 9 Ağustos Efrenci 1914, No:11971, s.1; Tasfir-i Efkâr, 10 Ağustos 1914, No:1164, s.3.

${ }^{66} \mathrm{O}$ günlerde Journal de Balkan bir Balkan İttifakı üzerinde dururken Echo de Bulgarie karşı olmamakla birlikte kalıcı ve yararlı bir yapının mümkün olmadığını ileri sürüyordu. Tasfir-i Efkâr, 15 Ağustos 1914, No:1169, s.1. Talat ve Halil Beylerin ziyaretlerinin başladığı dönemde, dış basında Türkiye, Romanya ve Bulgaristan'ın işbirliği ihtimali analiz ediliyordu. Ayrıca Balkan İttihadı'nın yeniden kurulması çabaları hakkında da haberler çıkmıştı. Tanin, 17 Ağustos Efrenci 1914, No:2030, s.4; Tasfir-i Efkâr, 17 Ağustos 1914, No:1171, s.3-4; "Bulgaristan”, Tanin, 18 Ağustos Efrenci 1914, No:2031, s.1; Tasfir-i Efkâr, 27 Ağustos 1914, No:1181, s.3. Bu haberler, Balkan
} 
Mebusan Reisi Halil (Menteşe) Beyler Bulgaristan üzerinden Romanya'ya gitmek üzere İstanbul'dan ayrılmışlard1 ${ }^{67}$. Ağustos başlarında Romanyalı yetkililerle Bulgar yetkililer arasında yaşanan bir takım temasların ${ }^{68}$ ardından gerçekleşen Talat ile Halil Beylerin ziyareti, 16 Ağustos'ta Sofya'da Bulgar yetkililerce karşılanmalarıyla başlamıştı ${ }^{69}$. Aynı gece Osmanlı Sefareti tarafından ziyafet düzenlenmişti. Talat Bey, Reis-i Vükela (başbakan) Radoslavof ile uzun bir görüşme gerçekleştirmişti ${ }^{70}$.

Tanin'in ifadesiyle "Asrın ve beşeriyetin en büyük felaketi karşısında" kalındığı bir dönemde ${ }^{71}$ Bulgar kaynakları iki hükümetin barışın korunması yönünde karar aldıklarını

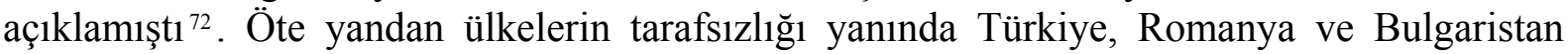
arasında ittifak yapılması beklentisi ortaya çıkmıştı ki bunun yürütücüsü olarak Talat Bey ön plana çıkıyordu ${ }^{73}$.

Tanin, Sofya temaslarıyla iki ülkenin yaşananlardan zarar görmemek için bir takım kararlar aldıklarını belirterek yorumunu "iki hükümetin kendilerini Avrupa'yı alt üst eden

İttihadı ile birlikte Balkanların tarafsızlığını da kapsayacaktı. Tanin, 19 Ağustos Efrenci 1914, No:2032, s.2. Tanin ise böyle bir ittifakın gerçekleştirilemeyeceği görüşünü savunacaktı. Daha dar kapsamda, küçük ölçekte anlaşma ya da uzlaşmaları savunan gazeteye göre "Hulasa, belki bir zaman gelecek tedric ve tekâmülün yardımı ile böyle bir kitle-i ittihadiye vücud bulacaktır; fakat bugün Balkan devletlerini Avrupa zelzelesinden tehlikesiz kurtarmak için tevessül edilecek çare bu değildir". "İzah Edelim”, Tanin, 24 Ağustos Efrenci 1914, No:2037, s.1; "Yeni Bir Delil", Tanin, 25 Ağustos Efrenci 1914, No:2038, s.1. Ahmet Agayef de Balkan İttihadı fikrinin hayata geçirilemeyeceğini düşünenler arasındaydı. Ahmet Agayef, "Siyasiyat-Balkan İttihadı", Tercüman-ı Hakikat, 17 Ağustos Efrenci 1914, No:11980, s.1. Yunus Nadi, "Balkan Balkanlılarındır" düşüncesinden hareketle çeşitli Balkan İttihadı projelerinin ortaya atıldığını; bu söylemlerden bazılarının konfederasyona kadar gittiğini aktarmıştı. Öte yandan ortaya atılan Balkan İttihadı projesinin gerçekleşmesinin hem Balkanlıların kendi aralarındaki sorunlar hem de Avrupa ile olan bağları nedeniyle imkânsız olduğunu; bu imkânsızlığın önemli kanıtlarının geçmişte yattığını ispatlamaya çalışmıştı. Yunus Nadi'ye göre geçmişte Türkleri dışarıda bırakan bir ittifak projesinin düş̧üğü durum herkesin gözü önündeydi. Yunus Nadi, "Siyasiyat-Balkanlar-Avrupa", Tasfir-i Efkâr, 24 Ağustos 1914, No:1178, s.1. İlginçtir; Tasfir-i Efkâr'ın 4 Eylül baskısına göre İngiltere, o günlerde Sofya Sefiri aracılığı ile Osmanlı Devleti'ni dışarıda bırakan bir Balkan İttihadı projesini gerçekleştirmeye çalışıyordu. Tasfir-i Efkâr, 4 Eylül 1914, No:1189, s.3.

${ }^{67}$ Tanin, 16 Ağustos Efrenci 1914, No:2029, s.1. Halil Bey anılarında otomobil ile Edirne'ye, oradan şimendiferle Bükreş’e gideceklerini, yolda Bulgaristan'a uğramaya karar verdiklerini aktarmaktadır. Çünkü Bulgaristan ile anlaşmış olarak Bükreş’e gitmeyi yararlı bulmuşlardı. "Eski Meclisi Mebusan Reisi Halil Menteşe'nin Hatıraları30”, Cumhuriyet, 17 Kasım 1946, No:7991, s.2. Zaten Tasfir-i Efkâr'da Bulgaristan'a uğranılacağı belirtilmemişti. Tasfir-i Efkâr, 16 Ağustos 1914, No:1170, s.4. Bayur ise otomobil ile yola çıkıp Sofya'ya vardıklarını belirtmektedir. Bayur. Türk Inkılâbı Tarihi, c.III/I, s.111.

${ }^{68}$ Tercüman-ı Hakikat, 4 Ağustos Efrenci 1914, No:11966, s.2; Tercüman-ı Hakikat, 5 Ağustos Efrenci 1914, No:11967, s.2; Tasvir-i Efkâr, 6 Ağustos 1914, No:1160, s.4.

${ }^{69}$ Tasfir-i Efkâr, 16 Ağustos 1914, No:1170, s.4; Tasfir-i Efkâr, 18 Ağustos 1914, No:1172, s.1; Tanin, 18 Ağustos Efrenci 1914, No:2031, s.2.

${ }^{70}$ Tanin, 19 A ğustos Efrenci 1914, No:2032, s.3-4. Talat Bey’in 17 Ağustos’ta Bulgaristan Başvekili ile görüştüğü bilgisini veren Tasfir-i Efkâr, Sefarethane'deki ziyafet gününü de 17 Ağustos olarak tarihlendirmektedir. Tasfir-i Efkâr, 19 Ağustos 1914, No:1173, s.1,4. Sofya Sefiri Ali Fethi Bey (Okyar) idi. Sofya'daki faaliyetleri hakkında bkz.: Fatih M. Sancaktar. 2011. Ali Fethi (Okyar) Bey'in Bulgaristan Sefirliği Dönemindeki Faaliyetleri (Ekim 1913-Aralık 1917). Atatürk Araştırma Merkezi Dergisi, c.XXVII, sy.81 (Kasım), s.577-602.

71 "Sevişelim ve Çalışalım”, Tanin, 21 Ağustos Efrenci 1914, No:2034, s.1.

72 Tasfir-i Efkâr, 21 Ağustos 1914, No:1175, s.4; Tanin, 20 Ağustos Efrenci 1914, No:2033, s.4.

73 Tanin, 21 Ağustos Efrenci 1914, No:2034, s.3-4. Talat Bey’in, Livadia gezisini yorumlayan bir Bulgar diplomatın şu sözleri bu düşüncenin ne kadar geriye gittiğini göstermektedir: "Talat Bey'in Livadia'yı ziyaretinin bir ehemmiyet-i umumiye-i siyasiyeyi haiz olmasina ihtimal vermiyorum. Ziyaret-i vakıanın iktisadiyeyi hal ve fasletmek maksadına mübteni bulunduğunu zannetmekteyim. Mahaza Livadia'da vukua gelecek mülakatlar esnasında Balkanlar ahval-i siyasiyesinden bahsedilmesi pek muhtemeldir. Benim fikrimce Türkiye için gayet mühim olan adalar meselesinin çare-i tesviyesi Livadia'da aranmayıp, komşu dost hükümetler payitahtlarında taharri edilmelidir. Bazı alakadar düvel-i muazzama canibinden iltizam edildiği vechile Türkiye ile Bulgaristan ve Romanya arasında Yunanistan aleyhine bir ittifak akdi Adaların atisi ile Makedonya'daki milliyetler mesailini hüsn-i suretle hal ve fasledebilmek için çare-i yeganedir". Özel, a.g.m., s.253. 
kasırgadan muhafaza için anlaştıklarını gösteren bir neticeden başka bir şey değildir" ifadesiyle ortaya koymuştu ${ }^{74}$. Üstelik bazı Bulgar siyasetçilere (Tanin'in aktarımıyla bazı Bulgar kabinesi üyelerine) göre Romanya'nın Bulgaristan'ın isteklerini kabul etmesi halinde Türkiye-Romanya ve Bulgaristan arasında bir ittifak yapılabilirdi ${ }^{75}$.

20 Ağustos'ta Talat ve Halil Beyler Bükreş'e ulaşmışlar; Bratianu ile görüşerek nezaretleri ziyaret etmişlerdi ${ }^{76}$. 21 Ağustos akşamı Romanya Hariciye Nazırı Porumbaru tarafından Türk misafirlerin şerefine ziyafet verilmişti ${ }^{77} .25$ Ağustos'ta Türk temsilciler, Kral tarafından huzura kabul edilecekleri Sinaya'ya gitmişlerdi ${ }^{78}$.

Talat ve Halil Beyler, Bulgaristan ve Romanya'da büyük bir memnuniyetle karşılanmışlard $1^{79} \mathrm{ki}$ bu, Tanin tarafından önemli ve olumlu bir gelişme olarak kaydedilmişti. Ayrıca Bükreş’te Adalar Meselesi merkezli olmak üzere Yunanistan temsilcileriyle görüşüleceğini haber yapmışt1 ${ }^{80}$. Talat Bey de Minerva gazetesine verdiği demeçte, Adalar Meselesi'nin çözümlenmesi hakkında ve Balkanlarda barışa ihtiyaç duyulduğu yönünde açıklamalarda bulunmuştu ${ }^{81}$.

74 "Bükreş Yolunda", Tanin, 23 Ağustos Efrenci 1914, No:2036, s.1. Bulgar basınına göre tren hatlarında kolaylaştırıcı tedbirlerin yanında ortak sınırlarda asker azaltılması gibi kararlara varılmıştı. Tercüman-ı Hakikat, 22 Ağustos Efrenci 1914, No:11984, s.2; Tanin, 24 Ağustos Efrenci 1914, No:2037, s.3. Bulgar basınından aktarım yapan Tasfir-i Efkâr'a göre Türkiye ile Romanya, Bulgaristan'ın Makedonya üzerindeki haklarını tanıyacak ve Bükreş Antlaşması üstünde Bulgaristan'ın değişiklik isteklerine müsaade edeceklerini taahhüt edeceklerdi. Ayrıca Romanya savaşa girmek zorunda kalırsa diğerleri tarafsız kalacaklardı. Yine bazı Bulgar gazetelere göre Bulgarlar sınırlar hakkında Romanya'nın fedakârlıkta bulunmasını istemişti. Tasfir-i Efkâr, 26 Ağustos 1914, No:1180, s.3. Eylül başlarında ise Tasfir-i Efkâr, bir Bulgar nazırının Türkiye ile tarafsızlık üzerine anlaştıkları yönündeki açıklamasına yer verecekti. Tasfir-i Efkâr, 7 Eylül 1914, No:1192, s.2. Babacan, Sabah ve Tanin gazetelerinin 2124 Ağustos 1914 tarihli baskılarından hareketle Talat Bey’in seyahatinin basında büyük ölçüde yer aldığını, karşılama ve ziyaretlerden bahsedildiğini yapılan anlaşmanın gizli tutulduğunu kaydetmektedir. Babacan, a.g.e., s.122-123. Bu doğru olmakla birlikte yukarıdaki örneklerden de anlaşılabileceği üzere iki ülke arasında bir uzlaşma ya da antlaşmaya varıldı ̆̆ değerlendirilebilmektedir. Bayur, antlaşma şartlarını ana hatlarıyla sıralamıştı. Bunlar; taraflardan biri Balkanlıların saldırısına maruz kalırsa diğeri saldırganlara karşı mücadele edecek, taraflar diğeriyle anlaşmadan Balkan devletlerine savaş ilan etmeyecek, orduların işbirliği hakkında bir mukavele yapılacak şeklinde özetlenebilir. Bayur. Türk Inkılâbı Tarihi. c.III/I, s.111-112.

${ }^{75}$ Tasfir-i Efkâr, 24 Ağustos 1914, No:1178, s.3; Tanin, 24 Ağustos Efrenci 1914, No:2037, s.3.

${ }^{76} 21$ Ağustos tarihli haberlerde Talat Bey'in Sinaya’ya ulaştığı bilgisiyle karşılaşılmaktadır. Tanin, 22 Ağustos Efrenci 1914, No:2035, s.3-4; Tasfir-i Efkâr, 21 Ağustos 1914, No:1175, s.4; Tasfir-i Efkâr, 22 Ağustos 1914, No:1176, s.3-4.

77 Tasfir-i Efkâr, 23 Ağustos 1914, No:1177, s.3; Tanin, 23 Ağustos Efrenci 1914, No:2036, s.2. Mustafa Ragıb Esatlı, Talat Bey'in seferberlik ilanından sonra yaşanan sıkıntılara bağlı olarak Şehremini Cemil Paşa'nın (Topuzlu) isteği ile Romanya'da un alımıyla da ilgilendiğini anlatmaktadır. Mustafa Ragıb Esatlı. (2007). Ittihat ve Terakki'nin Son Günleri, Suikastlar ve Entrikalar. Haz.: İsmail Dervişoğlu, Bengi Yayınları, İstanbul, s.92104.

${ }^{78}$ Tanin, 26 Ağustos Efrenci 1914, No:2039, s.4. Yunan temsilciler beklendiğinden Talat Bey, Sinaya’ya gidişini ertelemişti. Tasfir-i Efkâr, 23 Ağustos 1914, No:1177, s.4; Tanin, 23 Ağustos Efrenci 1914, No:2036, s.4. Türk tarafı görüşme için Sinaya'yı uygun bulurken Yunan delegeler Bükreş’i tercih etmişlerdi. Tanin, 24 Ağustos Efrenci 1914, No:2037, s.4.

${ }^{79}$ Bazı yayın organları Talat Bey'in Çar Ferdinand tarafından kabul edildiğini aktarmışlar ve nihayet 19 Ağustos'ta Bulgar Telgraf Ajansı, Çar Ferdinand'ın aynı akşam Talat Bey’i huzura kabul ettiğini açıklamıştı. Tercüman-ı Hakikat, 20 Ağustos Efrenci 1914, No:11982, s.1,2; Tasfir-i Efkâr, 20 Ağustos 1914, No:1174, s.3; Tasfir-i Efkâr, 21 Ağustos 1914, No:1175, s.3.

${ }^{80}$ Tanin, 23 Ağustos Efrenci 1914, No:2036, s.1-3. Bu dönemde basında, tarafların anlaşabileceklerine yönelik iyimser yazılara rastlanmaktadır. "Bükreş Mülakatı Etrafında", Tanin, 25 Ağustos Efrenci 1914, No:2038, s.4.

${ }^{81}$ Tanin, 26 Ağustos Efrenci 1914, No:2039, s.2. Basında Balkan ülkelerinin karşılıklı görüş ve çelişkilerini yansıtan, bu bağlamda bir ittifak fikrini ele alan aktarımlara rastlanmaktadır. "Yunanistan'da", Tanin, 27 Ağustos Efrenci 1914, No:2040, s.3; Tanin, 30 Ağustos Efrenci 1914, No:2043, s.2. Öte yandan bazı Romanya gazeteleri, Balkan İttihadı gibi bütünsel ve yaygın bir anlaşmanın yapılması imkânı olduğunu yazmışlardı. Bunun temel şartı ise devletlerarasında toprak değişiklerinin gerçekleştirilmesiydi. Gazetelere göre bu konuda, -Ege adalarının bir 
Tasfir-i Efkâr'da Yunus Nadi, yaşanan temasların Bükreş Antlaşması'nın yeni şartlar çerçevesinde değerlendirilmesiyle ilgili olabileceğini söylerken Birinci Dünya Savaşı'nın yarattığı tehditler içinde Osmanlı, Bulgaristan ve Romanya devletleri arasında Balkan dengeleri açısından bir uzlaşmaya varılabileceği kanaatini ifade edecekti ${ }^{82}$.

22 Ağustos günü Zaimis ve Politis’ten oluşan Yunan heyeti Bükreş'e ulaşacaktt ${ }^{83} .24$ Ağustos kaynaklı bir haber ise Türk-Yunan görüşmelerinin resmen başladığı yönünde idii ${ }^{84}$. Gazeteler Türk ve Yunan heyetlerinin 25 Ağustos'ta Romanya Kralı ile görüştüklerini yazmışlard ${ }^{85} .27$ Ağustos tarihli başka bir haberde ise bir gün önce Osmanlı Sefarethanesi'nde tarafların görüştükleri bilgisi verilmiştiti ${ }^{86}$.

31 Ağustos'ta yapılan Türk-Yunan görüşmelerinden sonra Talat Bey, Bulgaristan üzerinden İstanbul'a gelmek üzere Romanya'dan ayrılmış ve 2 Eylül'de İstanbul'a ulaşmıştı. Halil Bey ise görüşmeleri sürdürmek için Bükreş’te kalmışt ${ }^{87}$. Yunus Nadi, Talat Bey'in dönerken Halil Bey’in Bükreş’te kalmasını Yunanlılarla anlaşılamasa bile Romanya ile anlaşıldığ yönünde yorumlayacakt1 ${ }^{88}$. Talat Bey ise kendisi ile yapılan röportajda Romanya'ya sadece Adalar Meselesi’ni çözümlemek üzere gittiklerini açıklamıştı ${ }^{89}$.

Ağustos sonları ve Eylül başlarında gazete haberleri, Türk-Yunan görüşmelerinin olumlu bir seyir takip etmemesine rağmen Türk-Romen görüşmelerinin Bulgaristan'1 da

kısmının Türkiye’ye terk edilmesinin benimsenmesinden de anlaşılacağı üzere- Sırbistan dışında anlaşılmıştı. Tasfir-i Efkâr, 26 Ağustos 1914, No:1180, s.3.

${ }^{82}$ Yunus Nadi, "Siyasiyat-Sofya'dan Sonra Bükreş'de”, Tasfir-i Efkâr, 26 Ağustos 1914, No:1180, s.1. Ahmet Agayef, bir yandan Bükreş Antlaşması'nın oluşturduğu düzenin devam edemeyeceğini ve bir yandan da devletlerin büyük fedakarlıklar yapamayacaklarını belirterek Balkan İttihadı fikrinin bu şartlar altında bir sonuca ulaşmayacağını ileri sürmüştü. Ayrıca bu fikrin ya bir entrika ürünü olduğunu ya da aksine ciddi bir politikayı ifade ettiğini değerlendirirken ciddi bir ittihadın ancak Türkiye, Bulgaristan ve Romanya arasında gerçekleşebileceğini düşünmekteydi. Ahmet Agayef, "Siyasiyat-Yine Balkan İttihadı", Tercüman-ı Hakikat, 24 Ağustos Efrenci 1914, No:11986, s.1.

${ }^{83}$ Tasfir-i Efkâr, 24 Ağustos 1914, No:1178, s.3; "Eski Meclisi Mebusan Reisi Halil Menteşe'nin Hatıraları-30”, Cumhuriyet, 17 Kasim 1946, No:7991, s.2.

${ }^{84}$ Tasfir-i Efkâr, 27 Ağustos 1914, No:1181, s.3; Tanin, 27 Ağustos Efrenci 1914, No:2040, s.1.

${ }^{85}$ Tasfir-i Efkâr, 26 Ağustos 1914, No:1180, s.4; Tasfir-i Efkâr, 27 Ağustos 1914, No:1181, s.3; Tanin, 27 Ağustos Efrenci 1914, No:2040, s.1.

${ }^{86}$ Tercüman-ı Hakikat, 27 Ağustos Efrenci 1914, No:11989, s.2; Tanin, 28 Ağustos Efrenci 1914, No:2041, s.2; Tasfir-i Efkâr, 28 Ağustos 1914, No:1182, s.3.

${ }^{87}$ Tercüman-ı Hakikat, 1 Eylül Efrenci 1914, No:11994, s.2; Tercüman-ı Hakikat, 2 Eylül Efrenci 1914, No:11995, s.2; Tanin, 2 Eylül Efrenci 1914, No:2046, s.2-4; Tasfir-i Efkâr, 2 Eylül 1914, No:1187, s.2,4; Tanin, 3 Eylül Efrenci 1914, No:2047, s.2-3; Tasfir-i Efkâr, 3 Eylül 1914, No:1188, s.1; "Eski Meclisi Mebusan Reisi Halil Menteşe'nin Hatıraları-30", Cumhuriyet, 17 Kasım 1946, No:7991, s.2.

${ }^{88}$ Yunus, Nadi, “Siyasiyat-Talat Bey’in Avdeti”, Tasfir-i Efkâr, 2 Eylül 1914, No:1187, s.1. Yunus Nadi, Eylül'ün ilk günlerinde Romanya'daki temaslarından hareketle kaleme aldığı yazısında Romanya'nın atmosferini ve çelişkilerini aktarırken "... Hangi tarafin kılıcı keskin çıkarsa o tarafa meyl eder gibi görünerek buhrandan mümkün olduğu kadar karlı çıkmak hülyasındadırlar... Ne o doğru ne de bu. Bütün gayretler hep beyhude. Romanya, hangi taraf galip çıkarsa haritasını ona göre tanzim etmek üzere bekliyor" ifadelerine yer vermişti. Yunus Nadi, "Siyasiyat-Romanya'nın Siyaseti”, Tasfir-i Efkâr, 8 Eylül 1914, No:1193, s.1-2. Yunus Nadi, tarafsızlığın Romanya' da nasıl değerlendirildiğini anlatan benzer içerikte bir diğer yazısını ertesi gün yayınlamıştı. Yunus Nadi, “Bitaraflıkların Envai İçinde!", Tasfir-i Efkâr, 9 Eylül 1914, No:1194, s.1. Yunus Nadi, Romanyalıların Türkleri gerçekte pek tanımadıklarını ileri sürdüğü bir yazısında kendisinin tarafsızlığını vurgulan Romanyalı siyasetçilerden birinin "Romanya'da ahalinin ekseriyeti Itilaf-ı Müselles taraftarıdır. Fakat hükümet Alman tarafina meyyaldir" sözleri yine bu ülkenin çelişkisini ortaya koyuyordu. Yunus Nadi, "Romanyalılar ve Biz", Tasfir-i Efkâr, 10 Eylül 1914, No:1195, s.5. Yazar, Balkan Savaşları sürecini de hatırlatacak şekilde Romanya ve Balkanlar üzerine de bir yazı kaleme almıştı. Yunus Nadi, "Romanya ve Balkanlar", Tasfir-i Efkâr, 14 Eylül 1914, No:1198, s.3.

${ }^{89}$ Devam eden görüşmeleri Halil Bey ile Bükreş Sefiri Safa Bey yürütecekti. Tasfir-i Efkâr, 3 Eylül 1914, No:1188, s.4. Dış basında Osmanlı delegelerinin Adalar Meselesi hakkında ciddi bir duruş sergiledikleri yönünde haberler çıkmıştı. Tasfir-i Efkâr, 7 Eylül 1914, No:1192, s.2. 
kapsayacak bir ittifak çizgisinde başarıyla sürdüğü yönünde idi90. Ağustos sonlarına doğru Sofya'da bulunan ve Tasfir-i Efkar'ın ifadesiyle "bir Bulgar muhibi olarak" tanınan Besarya Efendi, gazetelere verdiği demeçte bir Balkan İttifakı'nın mümkün olduğunu ancak bunun için Sırbistan ile Yunanistan'ın bazı mevkileri Osmanlı Devleti'ne vermeleri gerektiğini söylemiş ve nihayet " $\mathrm{Bu}$ sebepledir ki bugün ancak Türkiye, Bulgaristan ve Romanya arasında akd edilecek bir ittifak bahsolunabilir" demişti91. Öte yandan Türk basınından anlaşıldığına göre, Türk heyeti Romanya'da temaslarına başladığı sıralarda Bulgaristan kamuoyu ülkenin tarafsızlığını ön plana alan tartışmalar yaşıyordu92. Romanya'da ise Adevarul ve Dimineata gibi gazetelerde 25 ve 27 Ağustos 1914 tarihlerinde Türk-Alman ilişkileriyle ilgili yazılar çıkmıştı. Yazılar, Osmanlı ordusundaki Alman subaylar ve Almanya'dan getirilen savaş mühimmatını merkez alıyordu. Bunlar, Osmanlı Sefarethanesi'nin Romanya hükümeti nezdinde böyle yayınların men edilmesi için girişimde bulunmasını gündeme getirecekti93. Fakat Osmanlı cephesindeki rahatsızlığa rağmen benzer yayınlar ilerleyen tarihlerde de Romanya basınında görülecekti.

Talat Bey'in dönüşünden sonra da Bükreş’teki Türk-Yunan görüşmeleri olumlu bir çizgiye ulaşmamıştı. Bu arada basın haberlerinden tarafların birbirlerini sorumlu tuttukları ve sorunların çözümündeki yetersizlik nedenini muhataplarında aradıkları anlaşılmaktadır ${ }^{94} .4$ Eylül'deki temaslardan ${ }^{95}$ sonra 8 Eylül'de gerçekleşecek görüşme etabı ise ertelenecekti ${ }^{96}$. Tanin, bu ertelemeyi değerlendirirken Yunanlıların Türklerle anlaşmaktan çok Bükreş’teki atmosferi tanıma kaygısında olduklarını ileri sürecekti. Bu arada tarafların 11 Eylül görüşmesi de sonuçsuz kalmışt ${ }^{97}$. Ardından Halil Bey de Romanya' dan ayrılacak ve Bulgaristan üzerinden 13 Eylül'de Ayastefanos'a ulaşacakt1 ${ }^{98}$.

Halil Bey’in İstanbul'a dönüşünden sonra, Eylül ortalarından itibaren İstanbul'daki bazı yayın organlarının Romanya'nın tarafsızlığına vurgu yapan haberleri dikkat çekiyordu ${ }^{99}$. Bu

\footnotetext{
${ }^{90}$ Tanin, 1 Eylül Efrenci 1914, No:2045, s.3; Tasfir-i Efkâr, 1 Eylül 1914, No:1186, s.2. Aynı dönemde Tanin gibi bazı gazetelerde Yunanlıların Makedonya Müslümanlarına kötü davrandıkları ve Müslümanların mallarına el koydukları haberleri çıkmıştı. "Yunanistan Şaşırdı mı?”, Tanin, 4 Eylül Efrenci 1914, No:2048, s.1.

91 Tasfir-i Efkâr, 28 Ağustos 1914, No:1182, s.3. Benzer bir yaklaşım bazı Bükreş gazetelerinde çıkmıştı. Bunlardan birine göre Talat Bey, Bükreş ziyareti münasebetiyle Romanya Hükümeti'ni yeniden oluşturulacak tarafsız ve bağımsız ittifaka katmaya çalışacaktı. Yeni Balkan İttifakı, Balkanlarda arazi taksimatında etkili olabilecekti. Bir başka gazete ise Balkan İttihadı'nın programını şöyle vermişti: “Yunan Hükümeti, mevzu-ı bahs olan adaları Türkiye'ye iade edecek, Bulgaristan Kavala'yı Yunanistan da Epir'i alacaklar, Sırbistan Hükümeti Makedonya'daki arazisini Bulgaristan'a terk ederek ona mukabil Adriyatik sahilinde bir limana malik olacaktır". Tercüman-ı Hakikat, 5 Eylül Efrenci 1914, No:11998, s.2.

92 Tasfir-i Efkâr, 22 Ağustos 1914, No:1176, s.3; Tasfir-i Efkâr, 23 Ağustos 1914, No:1177, s.3.

${ }^{93}$ BOA, DH.EUM.5.Şb, Dosya No:1, Gömlek No:41.

${ }^{94}$ Tanin, 6 Eylül Efrenci 1914, No:2050, s.3. Bu tutum görüşmelerin kesilmesinden sonra da sürecekti. Tanin, 17 Eylül Efrenci 1914, No:2060, s.4. Yunan delegelerin “Adalar Yunanistan'a icar edilsin, padişah oraya bir Yunanlı vali tayin etsin" karşı önerisinden sonra Talat ve Halil Beyler Bulgaristan ile birleşerek Yunanistan ve Sırbistan'a saldırma kararlılıklarını Alman ve Avusturya elçilerine bildirip ülkelerinin görüşlerini sormuşlardı. Almanya cephesi, Osmanlı kuvvetlerinin bu yönde kullanılmasını istememişti. "Eski Meclisi Mebusan Reisi Halil Menteşe'nin Hatıraları-30", Cumhuriyet, 17 Kasım 1946, No:7991, s.2; Bayur. Türk İnkılâbı Tarihi, c.III/I, s.128. 95 Tasfir-i Efkâr, 7 Eylül 1914, No:1192, s.3.

${ }^{96}$ Tanin, 9 Eylül Efrenci 1914, No:2053, s.4. Yunus Nadi, biri Osmanlı diğeri Yunan Sefarethanesi'nde olmak üzere iki görüşme yapıldığını ve Türk tarafının Adalar'da Osmanlı hakimiyetinin sağlanması talebinde bulunduğunu kaydetmişti. Yunus Nadi, "Bükreş Müzakereleri”, Tasfir-i Efkâr, 12 Eylül 1914, No:1196, s.1-2.

97 “Bükreş Müzakeratı", Tanin, 13 Eylül Efrenci 1914, No:2056, s.1,2.

${ }^{98}$ Tanin, 14 Eylül Efrenci 1914, No:2057, s.3-4; Tasfir-i Efkâr, 14 Eylül 1914, No:1198, s.4; Tasfir-i Efkâr, 15 Eylül 1914, No:1199, s.2. Talat ve Halil Beylerin Romanya'ya gidiş ve dönüşlerindeki 60.710 (altmışbinyediyüzon) kuruşluk masrafın Hazine-i Maliyece Masarif-i Gayr-i Melhuze Tertibi’nden karşılanması uygun bulunmuştu. BOA, BEO, Dosya No:4313, Gömlek No:323448; BOA, $M V$, Dosya No:193, Gömlek No:14. 99 Tanin, 20 Eylül Efrenci 1914, No:2063, s.4. Bu yayınlar ilerleyen günlerde de sürecekti. Tanin, 27 Eylül Efrenci 1914, No:2070, s.4.
} 
arada Romanya'nın atmosferi hızlı gelişmelere sahne olmaya başlamıştı. Eylül başlarında Fransa gibi ülkeler lehine gösteriler yapılmışt1 ${ }^{100}$. Eylül ortalarında ise Balkan İttihadı fikri, propaganda aracı olarak kullanılmaya başlanmıştı. Bu arada Bükreş'te çıkan ve Üçlü İtilaf'ın propagandasını yapan bir gazete Avusturya ve Türkiye gibi ülkelere karşı kamuoyu oluşturmaya çalışmışt ${ }^{101}$. Bu yöndeki toplumsal hareketliliklere paralel olarak Eylül ortalarında Kral başkanlığında toplanan Romanya Meclis'i tarafsızlık vurgusuna tekrar ihtiyaç duymuştu ${ }^{102}$. Böyle haberler, Balkanlarda İtilaf ve İttifak Devletleri arasındaki mücadelenin şiddetlendiğini gösteriyordu ${ }^{103}$. Balkanların yavaş yavaş karışmaya başladığını ileri süren Tanin, Romanya'nın atacağı adımın coğrafyanın geleceği açısından çok önemli olduğuna işaret edecekti ${ }^{104}$.

${ }^{100}$ Tasfir-i Efkâr, 8 Eylül 1914, No:1193, s.3.

101 "Entrikalar İçinde", Tanin, 20 Eylül Efrenci 1914, No:2063, s.1. Halil Bey, eski başvekil olarak nitelendirdiği Tache Ionescu'nun Sinaya'da bir gazinoda kendisine "Ancak süngü ile Rumen milleti Avusturya'ya yardıma sevkedilebilir" dediğini aktarmaktadır. "Eski Meclisi Mebusan Reisi Halil Menteşe'nin Hatıraları-31", Cumhuriyet, 19 Kasım 1946, No:7993, s.2. Bunu doğrular şekilde Tasfir-i Efkâr, Ağustos başlarında Romanya'da halkın Avusturya karşıtllı̆ıına dikkat çeken kısa haberleri yayınlamıştı. Tasfir-i Efkâr, 7 Ağustos 1914, No:1161, s.2. Bu haberler, çoğunlukla Bükreş’te bulunan Yunus Nadi tarafindan aktarılmıştı. Haberlere göre Romanya'da karışıklıklar ve özellikle hükümete karşı muhalefet artmıştı. Ancak muhalif partiler, Kral'ın öncülüğünde yapılacak toplantıda alınan kararları kabul edeceklerini açıklayacaklardı. "Siyasiyat-Fikrin Galebesi", Tasfir-i Efkâr, 4 Eylül 1914, No:1189, s.1. Öte yandan Kral başkanlı̆̆ında ikinci kez olağanüstü bir toplantı yapılarak yol haritasının çizilmesinin kararlaştırıldığı haberleri de gazete sütunlarına yansımışı. Tanin, 27 Eylül Efrenci 1914, No:2070, s.4. Romanya'da bulunan Yunus Nadi, Rus ve Fransız sefirlerin propaganda için nasıl çalıștıklarını ve ülkedeki istikrarsız, çelişkili atmosferi anlatan bir yazıyı Eylül ortalarında kaleme almıştı. Yunus Nadi, "Buhran ve Cidal", Tasfir-i Efkâr, 15 Eylül 1914, No:1199, s.3. O günlerdeki başka bir yazısında "Bitaraflı̆̆ını ilan etmiş olan Romanya henüz bitaraflı̆̆ının şekil ve derecesini bile tayin edememiş bulunuyor. Dün Balkanlardaki müdahalesiyle pek büyük bir mevki kazanmıs olan bu memleketin bugün en küçük hükümetlere bile yakuştırlamayacak bir kararsızlık içinde yüzmesi insana hayliden hayliye garip görünüyor" ifadelerine yer vermişti. Bu ifadelerinden sonra Romanya'nın Balkan Savaşları sırasında aslında firsatçı bir müdahalede bulunduğunu ima etmiş ve sonuçta "Romanya siyasetinin ibresi daima Avrupa Harbi'nde daha kuvvetli çıkacak tarafi arayarak sallanıp durmaktadır" tanısını aktarmıștı. Yunus Nadi, "Romanya: Dün ve Bugün”, Tasfir-i Efkâr, 16 Eylül 1914, No:1200, s.3.

102 "Romanya'da Son Hafta”, Tanin, 22 Eylül Efrenci 1914, No:2065, s.1. Tercüman-ı Hakikat, 19 Eylül'de “bir meclis-i fevkalade"nin toplandığını yazmıștı. Tercüman-ı Hakikat, 21 Eylül Efrenci 1914, No:12013, s.1.

${ }^{103}$ Agayef, bu dönemde Balkan basın ve siyasetinde İtilaf Devletleri lehine bir akım oluştuğunu yazacaktı. Ayrıca yine aynı süreç içinde kaleme aldığı Romanya hakkındaki yazılarında daha önce belirttiği Romanya'da farklı akımların/görüşlerin bulunmadığı, gerçekte bunların Romanya'nın oyalama taktiğinden ibaret olduğu yönündeki fikrini geçersiz kılmış olacaktı. Ahmet Agayef, "Siyasiyat-Balkan Devletleri Müttefikan Hareket Edebilirler mi?", Tercüman-ı Hakikat, 24 Eylül Efrenci 1914, No:12016, s.1; Ahmet Agayef, "Siyasiyat-Balkanlarda", Tercüman-ı Hakikat, 3 Teşrin-i Evvel Efrenci 1914, No:12025, s.1; Ahmet Agayef, "Siyasiyat-Son Vaziyet", Tercüman-ı Hakikat, 4 Teşrin-i Evvel Efrenci 1914, No:12026, s.1. Agayef, Ekim ortalarına doğru yayın organları üzerinden Balkanlar'daki İtilaf ve İttifak Devletleri'nin mücadelesini değerlendirmiş; bunların Balkan Devletleri üzerindeki etkilerini yorumlarken Bükreş Antlaşması'nın yarattığı şartları ve Buxton kardeşlerin faaliyetlerini de ele almıştı. Ahmet Agayef, "Siyasiyat-Balkan'da", Tercüman-ı Hakikat, 10 Teşrin-i Evvel Efrenci 1914, No:12032, s.1.

104 "Balkanların Tali'i”, Tanin, 24 Eylül Efrenci 1914, No:2067, s.1. Gazete Bulgaristan gibi bazı Balkan coğrafyalarında eski Londra Balkan Komisyonu Başkanı Noel Buxton'un İngiltere lehine propaganda faaliyeti yürüttüğünü ileri sürmüştü. Tanin, 26 Eylül Efrenci 1914, No:2069, s.3. Tanin'e göre Bulgaristan'a yönelik İtilaf propagandası ilerleyen günlerde de sürmüştür. Tanin, 3 Teşrin-i Evvel Efrenci 1914, No:2076, s.3. Buxton kardeşler ise 15 Ekim'de Bükreş'te silahlı saldırıya uğramışlardı. Saldırganın gazeteci Hasan Tahsin Recep Efendi olduğu belirlenmişti. Tercüman-ı Hakikat, 16 Teşrin-i Evvel Efrenci 1914, No:12038, s.2; Tanin, 17 Teşrin-i Evvel Efrenci 1914, No:2090, s.3-4. Agayef ise Buxtonların faaliyetleri hakkında yazı yazmış ve Balkanlarda binlerce İslam unsurunun ölümüne neden olduklarını belirtmişti. Ahmet Agayef, "Siyasiyat-Bakston Biraderlerin Maceraları, Tercüman-ı Hakikat, 16 Teşrin-i Evvel Efrenci 1914, No:12038, s.1. İzmir Yunanlılar tarafindan işgal edildiğinde tepkinin ve direnişin simgesi olan Hasan Tahsin Bey için Kazım Özalp "Şehir içerisinde çarpışmalar olmuş, subaylar, askerler ve halktan birçoğu şehit edilmişler ve bu arada evvelce 'Bacston'lara Romanya'da suikast teşebbüsünde bulunan Hasan Tahsin Recep Bey ve sair tanınmıs bazı kimseler de nefslerini ve milli şereflerini müdafaa ederken şehit olmuşlardı" diye yazacaktı. Kazım Özalp. (1998). Milli Mücadele 1919-1922. c.I, TTK Yayınları, Ankara, s.11. 
Aynı dönemde, daha önce Romanya'da farklı kesimlerin farklı taraflara eğilimli olmalarını bir manevra olarak değerlendiren Agayef, Eylül sonlarına doğru Romanya'daki karışıklıkları kaleme almış ve hükümetin tarafsızlığına karşı muhalefetin ülkeyi İtilaf yanında savaşa sokmaya çalıştığını ileri sürmüştü. “... akıl ve menfaatin kalp ve hissiyata galip olması lazımdır. Fakat Romanya'nın şimdiki vaziyetinde akıl ve menfaat de kalp ve hissiyatla beraberdir" diyen Agayef, Romanya'nın atacağı adımların Balkanlarda zincirleme reaksiyona sebep olabileceğini değerlendirmişti ${ }^{105}$.

Journal de Balkan gazetesi ise Türk basınının Romanya'daki entrikalar hakkındaki yaklaşımına cevap vererek "kendi tarafindan Türkiye'yi de ecnebi entrikalarına maruz kalmak ve Almanların elinde alet olmakla" suçlamışt ${ }^{106}$. Öte yandan bu dönemde şiddetli karışıklıklara ve toplumsal hareketliliklere maruz kalan Romanya her şeye rağmen tarafsızlık konumunu sürdürmekteydi ${ }^{107}$.

Ekim başlarında ise Kral Carol'un Rusya yanlısı olması nedeniyle tahtan indirilmeye çalışıldığı ancak veliahdın tahtı kabul etmediği iddiaları gazetelere yansımıştı ki bu ülkenin karışık durumunun göstergesi olarak değerlendirilebilir ${ }^{108}$. Bu arada sürecin aktörlerinden I. Carol, 10 Ekim günü hayatını kaybetmişti ${ }^{109}$. Yeni kral Ferdinand'ın Carol'un çizgisini sürdüreceği yönündeki haberler kamuoyuna yansımışt ${ }^{110}$. Nitekim o günlerde Romanyalı yetkililer (Meclis-i Ayan Reisi gibi) ülkenin tarafsızlığını sürdüreceğini açıklayacaklard ${ }^{111}$.

Aynı dönemde Boğazların kapanması, Karadeniz'deki Rus filosu gibi sebeplerle Romanya vapur seferlerinin tatili gündeme gelmiş ve İstanbul sefiri aracılığ 1 ile bu kesinti engellenmeye çalışılmışt ${ }^{112}$. Artık 1913 sonlarında ivme yakalayan ve 1914 baharında gelişen Türk-Romen ilişkileri, gelişim hızını kaybetmeye başlamıştı. Savaşa endeksli politik yaklaşımlar iki ülkenin ilişkilerini kısa süre içinde zayıflatacak üstelik taraflar savaş sırasında farklı kutuplarda yer alacaklardı.

\section{Sonuç}

Osmanlı Devleti ile Romanya arasında 1913 sonbaharında kendini göstermeye başlayan siyasi temaslar kanalıyla özellikle 1914 baharında ciddi bir yakınlaşma kaydedilmişti ${ }^{113}$.

\footnotetext{
105 Ahmet Agayef, "Romanya”, Tercüman-ı Hakikat, 23 Eylül Efrenci 1914, No:12015, s.1.

${ }^{106}$ Ahmet Agayef, "Siyasiyat-Bir Cevab Münasebeti İle”, Tercüman-ı Hakikat, 6 Teşrin-i Evvel Efrenci 1914, No:12028, s.1.

${ }^{107}$ Ahmet Agayef, “Siyasiyat-Son Vaziyet”, Tercüman-ı Hakikat, 4 Teşrin-i Evvel Efrenci 1914, No:12026, s.1. Hükümet ile muhalif partiler arasındaki toplantıda Romanya'nın siyasetinin korunması kararı verilmişti. Tercüman-ı Hakikat, 4 Teşrin-i Evvel Efrenci 1914, No:12026, s.2.

${ }^{108}$ Tanin, 5 Teşrin-i Evvel Efrenci 1914, No:2078, s.4. Romanya'da tartışmalar ilerleyen tarihlerde de sürmüştü. 1915 Haziran'ında işçi sendikaları, esnaf ve tüccarlar savaş aleyhtarı gösteriler yapmaya yönelmişler, ülkedeki sosyalistler ise Romanya'nın tarafsızlığı lehinde karar almışlardı. BOA, DH.EUM.5.Şb, Dosya No:14, Gömlek No:7.

${ }^{109}$ Tercüman-ı Hakikat, 10 Teşrin-i Evvel Efrenci 1914, No:12032, s.1. Basında Carol hakkında oldukça olumlu yazılar kaleme alınmıştı. "Romanya Kralı'nın Vefatı", Tanin, 11 Teşrin-i Evvel Efrenci 1914, No:2084, s.1-2; Tanin, 12 Teşrin-i Evvel Efrenci 1914, No:2085, s.2,4; Tanin, 13 Teşrin-i Evvel Efrenci 1914, No:2086, s.2,4; Tanin, 14 Teşrin-i Evvel Efrenci 1914, No:2087, s.2.

${ }^{110}$ Tanin, 12 Teşrin-i Evvel Efrenci 1914, No:2085, s.3; Ahmet Agayef, “Siyasiyat-Romanya Kralı'nın Nutku”, Tercüman-ı Hakikat, 13 Teşrin-i Evvel Efrenci 1914, No:12035, s.1; Tanin, 14 Teşrin-i Evvel Efrenci 1914, No:2087, s.3.

${ }^{111}$ Tercüman-ı Hakikat, 15 Teşrin-i Evvel Efrenci 1914, No:12037, s.2.

112 Tanin, 15 Teşrin-i Evvel Efrenci 1914, No:2088, s.4. Romanya vapurunun seferlerinin, Ağustos'un ilk haftasıyla birlikte aksamaya başladığı anlaşılmaktadır. Tasfir-i Efkâr, 9 Ağustos 1914, No:1163, s.2; Tasfir-i Efkâr, 26 Ağustos 1914, No:1180, s.1.

${ }^{113} \mathrm{Bu}$ yakınlaşmanın göstergelerinden biri kuşkusuz tarafların birbirlerine verdikleri nişan ve madalyalardı. Süreç içinde Romanya tarafından Dâhiliye Nazırı Talat Bey’e birinci rütbeden Ritüval Romani Nişanı verilmişti. $B O A$, $B E O$, Dosya No:4246, Gömlek No:318385. Dâhiliye Nezareti Kalem-i Mahsus Müdürü Hasan Fehmi Bey’e
} 
Nitekim 1914 baharında gerçekleşen resmi (ya da gayrı resmi ${ }^{114}$ ) düzeydeki temaslar, I. Dünya Savaşı'nın hemen öncesinde Romanya ile Osmanlı Devleti arasında hızlı ve yoğun bir yakınlaşma süreci yaşandığını göstermektedir. Türk-Romen ilişkilerinin bu noktaya taşınmasında Talat Bey'in Bükreş ziyaretinin önemli derecede etkisinin bulunduğu rahatlıkla anlaşılabilmektedir. Öte yandan bu gezi, Balkanlarda Osmanlı'nın konumunu güçlendirme ve -her ne kadar çözümlenemeyecek olsa da- o günün şartları içinde Adalar Meselesi'nin sonlandırılmasına yönelik bir zemin oluşturulması ya da sorunun aşılması için kolaylaştırıcı bir hava oluşturma çabasıyla da ilişkilendirilebilir. Bunların yanında dönemin basınının yazı ya da yorumları da bir kaynaşma aracı olarak ele alınabilir.

Osmanlı Devleti, Birinci Dünya Savaşı'nın öncesinde başladığı ittifak arayışlarını, savaşın çıktığı süreçte de sürdürmüştü ${ }^{115}$. Dolayısıyla Talat Bey'in 1914 yılında Romanya'daki iki temas dizisini ve özellikle ikincisini ittifak arayışları bağlamında değerlendirmek yanlış olmayacaktır. Zaten savaş başladıktan sonra ittifak arayışlarına hız veren Osmanlı Hükümeti, 19 A ğustos 1914 tarihinde Bulgaristan ile gizli tutulan bir anlaşma imzalamayı başarmışt ${ }^{116}$.

Talat Paşa anılarında, Almanya ile ittifakın imzalanması ve Goeben ile Breslau'nun Çanakkale Boğazı'ndan içeri girmesi sonrasında Bulgaristan'ın durumundan emin olmak istedikleri için bu ülke ile temasları, Bükreş’te Yunanistan ile Adalar Meselesi'ni görüşme manevrasıyla/senaryosuyla örtüklerini anlatmaktadır. Ayrıca Bulgaristan'ın Romanya cephesini güvence altına almak istemesinden dolayı bu yönde çok çaba sarfettiklerini aktarmıştı. Fakat Bratianu, Bulgaristan’a tarafsızlıkları gerekçesiyle yazılı güvence vermemişti. Talat Paşa ise anılarda "Romanya'nın savaşın sonuna kadar tarafsızlığını korumaya kesin kararlı olduğuna inandık" demekteydi ${ }^{117}$.

üçüncü rütbe Kron de Romani Nişanı verilmişti. $B O A, B E O$, Dosya No:4256, Gömlek No:319160 (Diğer bazı Osmanlı memur ya da yetkililerine de nişanlar verilmişti. $B O A$, $B E O$, Dosya No:4249, Gömlek No:318660). Gazetelerde de 1914 baharında Romanya Kralı'nın Hasan Fehmi Bey ile İsmail Canbolat'a nişan verdiği haberlerine rastlanmaktadır. Enis Tahsin, "Talat Bey'in Seyahati”, Sabah, 31 Mayıs Efrenci 1914, No:8873, s.1; Tasfir-i Efkâr, 31 Mayıs 1914, No:1095, s.1. Romanya'da bulunduğu sırada Talat Paşa’ya büyük saygı gösteren Romanyalı tayyarecilere hükümet tarafından nişan verilmesinin kararlaştırıldığı, Türk basınında haber olmuştu. İkdam, 30 Mayıs Efrenci 1914, No:6204, s.3.

${ }^{114}$ Gayrı resmi temaslar ve özellikle Türk ve Romen öğrencilerin 1914 ve 1924 yıllarında gerçekleştirdikleri temaslar hakkında bkz.: Eminalp Malkoç. (2015). Birinci Dünya Savaşı'na Uzanan Süreçte Türk-Romen İlişkilerinden Bir Kesit: Türk ve Romen Öğrencilerin 1914 Gezileri/A Cross-Section from the Turkish-Roman Relations Approaching the First World War: The 1914 Tours of Turkish and Romanian Students. ICSS 2015 International Conference On Social Sciences (Pristina 10-11 April 2015), Conference Proceedings, Volume: I, s.463-470; Eminalp Malkoç. (2011). Büyük Savaş Öncesi Üniversitelilerin Diyalog Örneği: Türk ve Romen Öğrencilerin 1914 Gezileri. Türkoloji Kültürü, c.4, sy.8, s.109-123; Eminalp Malkoç. (2015). Cumhuriyet’in İlk Yillarında Balkanlarla Gayri Resmi Kültürel Temaslar: Darülfünun Öğrencilerinin Romanya Gezisi. 7. Uluslararast Atatürk Kongresi (Üsküp-Manastır 17-22 Kasım 2011), Bildiriler, c.III, Ankara, s.1945-1970.

${ }^{115}$ Osmanlı Devleti, savaş öncesinde Rusya, İngiltere ve Fransa ile anlaşmak istemiş fakat başaramamıştır. Tarihte Türk-Rumen Iliş̧kileri. (2006). Genelkurmay Atase ve Denetleme Başkanlığı Yayınları, Ankara, s.133. Osmanlı Devleti'yle Rusya arasında bir ittifak oluşturma çabaları Birinci Dünya Savaşı'nın başladığı günlerde de sürmüştü. Enver Paşa'nın İstanbul'daki Rus askeri ataşesi General Leontyev'le yaptığı görüşmeler ve Rusya'ya ittifak önerisi sonuca ulaşmamıştı. Özel, a.g.m., s.256-257.

116 Özçelik, a.g.m., s.263. Talat Paşa, anılarında Radoslavof'u ittifak eğiliminde bulduklarını ve herhangi bir saldırı karşısında birlikte savunmaya geçilmesini sağlayacak bir anlaşma imzalandığını belirtmektedir. Talat Paşa'nın Anıları. (2003). Haz.: Alpay Kabacalı, Türkiye İş Bankası Kültür Yayınları, İstanbul, s.35.

117 Talat Paşa'nın Anıları, s.31-36. Halil Bey'in anılarından bu dönemde Adalar Meselesi’nin çözümüne ağırlık verildiği anlaşılmaktadır. "Eski Meclisi Mebusan Reisi Halil Menteşe'nin Hatıraları-23”, Cumhuriyet, 8 Kasım 1946, No:7982, s.2; “Eski Meclisi Mebusan Reisi Halil Menteşe'nin Hatıraları-27”, Cumhuriyet, 13 Kasım 1946, No:7987, s.2. Yusuf Hikmet Bayur ise Talat Bey'in Romanya ve Bulgaristan'ın kazanılması konusunda 1srar ettiğine yönelik kayıtlar vermektedir. Bayur, Yusuf Hikmet, Türk Inkılâbı Tarihi, c.III/I, s.159-161. Ayrıca 14 Ağustos 1914 tarihli Encümen-i Vükela Zabıtları'na dayanarak vükelanın bir kısmınca Adalar Meselesi'nin Türkiye lehine çözülerek Bulgaristan'ın öne sürülmesi (Bulgaristan'ın seferberlik ilan etmesinin ve bundan sonra 
Talat Bey'in anılarındaki ifadelere rağmen Osmanlı basınında Romanya'nın çelişkili durumu hakkında birçok yazı çıkmıştı. Romanya'nın tarafsızlığının taraf seçememekten kaynaklandığını ileri süren Yunus Nadi, 20 Ağustos tarihli yazısında "Şu vaziyetler karşısında Romanya bi-taraflı̆̆ muhafazada israr edecektir demek, hal ve zamana tahakküm eden hakikatlerden gafil bulunmak demektir" diye yazacakt ${ }^{118}$. Üstelik Osmanlı cephesi, çok olumlu ilişkiler ağı içinde bulunulmasına rağmen Romanya ile anlaşma zemini bulamadığı gibi ${ }^{119}$ aksine Almanya'ya yakın görünen bu devlet bazı Bulgaristan toprağı kendisine vaat edilince ve uygun olduğunu düşününce İtilaf Devletleri safına katılacaktı ${ }^{120}$.

Sonuçta Osmanlı Devleti ile Romanya arasında ilişki düzeyinin Birinci Dünya Savaşı başlayıncaya kadar gelişen bir istikrara sahip olduğu söylenebilir. Hatta birbirlerine aracılık yaptıklarını anlamak da zor olmayacaktır. Buna rağmen iki ülke farklı cephelerde yer almışlardı. Romanya, savaşta İngiltere cephesinde yer aldığından 30 Ağustos 1916'da Osmanlı Devleti ile ilişkisini kesmişti. Bu şekilde sonuçlanan sürecin geride bir iz bıraktığı ileri sürülebilir. $\mathrm{Bu}$ iz, Balkan İttihadı düşüncesiyle kendini göstermektedir. Özellikle savaş geriliminin artmasıyla daha çok gündeme gelen bu düşüncenin ilerleyen yılları etkilediğini ya da örnek olduğunu söylemek güç olsa bile Balkan Savaşları'ndan sonra daha çok basın kanalıyla işlenen bu yaklaşımın -1930'ların ilk yarısında Balkan Konferansları'yla hayata geçirilemeye çalışılan ancak başarılamayan Balkan Birliği projesinin ardından- 9 Şubat 1934'te imzalanan Balkan Paktı ile tehditlere karşı güvence ve işbirliği sağlama, Romanya ile Türkiye'nin dahil olmaları ve Balkanları büyük güçlere karşı bağımsız hale getirme çabaları gibi benzer unsurları olduğu değerlendirilebilir ${ }^{121}$.

\section{Kaynakça}

\section{Arşiv Belgeleri}

Başbakanlık Osmanlı Arşivi (BOA), BEO, Dosya No:4246, Gömlek No:318385.

$B O A, B E O$, Dosya No:4249, Gömlek No:318660.

$B O A, B E O$, Dosya No:4256, Gömlek No:319160.

$B O A, B E O$, Dosya No:4313, Gömlek No:323448.

BOA, DH.EUM.5.Şb, Dosya No:1, Gömlek No:41.

BOA, DH.EUM.5.Şb, Dosya No:14, Gömlek No:7.

$B O A, D H . K M S$, Dosya No:63, Gömlek No:64.

$B O A, M V$, Dosya No:193, Gömlek No:14.

\section{Anı, Kitap ve Tezler}

\footnotetext{
harekete geçmesinin sağlanması), bunun gerçekleşmemesi halinde Türk-Bulgar-Romen ittifakıyla savaşa girilmesinin düşünüldüğünü; bu amaçlar doğrultusunda Talat ve Halil Beylerin Bulgaristan ve Romanya'ya gittiklerini ancak beklenen sonuçlar elde edilemeyince savaş taraftarlarının bir oldu bitti yarattıklarını değerlendirmektedir. Bayur. Türk İnkılâbı Tarihi. c.III/I, s.98-106.

${ }^{118}$ Yunus Nadi, "Siyasiyat-Romanya'nın Vaziyeti Hakkında Mülakat", Tasfir-i Efkâr, 20 Ağustos 1914, No:1174, s.1.

119 Özçelik, a.g.m., s.263.

${ }^{120}$ Almanya, hem Bulgaristan'ın hem de Romanya'nın kendi yanında hareket etmesi için Türkiye'nin harekete geçmesini ve iki devlete ön ayak olmasını isteyecekti. Bu arada Ağustos başlarında Berlin Ataşemiliteri Cemil Bey, Romanya'nın İttifak-1 Müselles'e katılacağının düşünüldüğünü aktarmaktadır. Öte yandan Enver Paşa, Eylül ayında Romanya hakkında kaygı duymaya başlayacaktı. Nitekim Romanya Hükümeti, daha önce vermiş olduğu sevkiyat iznini kaldırmıştı. Vahdet Keleşyılmaz. (1999). Belgelerle Türkiye'nin Birinci Dünya Savaşına Giriş Süreci. Erdem, XII/31 (Mayıs), s.139-153.

${ }^{121}$ Vurgulanan benzerliklerin belirlenmesi ve Balkan Konferansları kanalıyla kurulmaya çalışılan Balkan Birliği için bkz.: Eminalp Malkoç. (2014). 1930'ların İlk Yarısında Türk Basınının Penceresinden Balkan Konferansları ve Arnavutluk. 3. Uluslararası Dil ve Edebiyat Kongresi (Tiran 30 Ekim-1 Kasım 2014), Bildiri Kitabı 1, Tiran, s.189-212.
} 
Babacan, H. (1991). Mehmed Talât Paşa 1874-1921. Altınpost Yayıncılık, Ankara (2012).

Bayur, Y. H. (1991). Türk Inkılâbı Tarihi. c.I-IV, TTK, Ankara.

Sazanov, S. (2002). Kader Yılları, S. Sazonov'un Anıları-Rusya Eski Dışişleri Bakanı (19101916), Çev.: Betil Önuçak, Yay. Haz.: Sabahattin Özel, Derin Yayınları, İstanbul.

Esatl1, M. R. (2007). Ittihat ve Terakki'nin Son Günleri, Suikastlar ve Entrikalar. Haz.: İsmail Dervişoğlu, Bengi Yayınları, İstanbul.

Kurat, A. N. (2011). Türkiye ve Rusya, XVIII. Yüzyıl Sonundan Kurtuluş Savaşına Kadar TürkRus Ilisskileri (1798-1919). TTK Yayınları, Ankara.

Özalp, K. (1998). Milli Mücadele 1919-1922. c.I, TTK Yayınları, Ankara.

Talat Paşa'nın Anıları (2003). Haz.: Alpay Kabacalı, Türkiye İş Bankası Kültür Yayınları, İstanbul.

Tarihte Türk-Rumen Iliş̧kileri (2006). Genelkurmay Atase ve Denetleme Başkanlığı Yayınları, Ankara.

Til, E. T. (2004). Gazeteler ve Gazeteciler. Haz.: İbrahim Şahin, Bilge Yayınları, Ankara.

\section{Bildiri ve Makaleler}

Avcı, H. E. (2010). I. Dünya Savaşı Öncesinde Türk Hükümeti’nin Rus Baskısını Azaltma Girişimleri: Türk-Rus Komitesi'nin Kurulması ve Talat Bey'in Livadya Gezisi. İstanbul Üniversitesi Edebiyat Fakültesi Güney-Doğu Avrupa Araştırmaları Dergisi, sy.18, s.87-112.

Keleşyılmaz, V. (1999). Belgelerle Türkiye'nin Birinci Dünya Savaşına Giriş Süreci. Erdem, XII/31 (May1s), s.139-153.

Malkoç, E. (2014). 1930'ların İlk Yarısında Türk Basınının Penceresinden Balkan Konferansları ve Arnavutluk. 3. Uluslararası Dil ve Edebiyat Kongresi (Tiran 30 Ekim-1 Kasim 2014), Bildiri Kitabi 1, Tiran, s.189-212.

. (2015). Birinci Dünya Savaşı'na Uzanan Süreçte Türk-Romen İlişkilerinden

Bir Kesit: Türk ve Romen Öğrencilerin 1914 Gezileri/A Cross-Section from the TurkishRoman Relations Approaching the First World War: The 1914 Tours of Turkish and Romanian Students. ICSS 2015 International Conference On Social Sciences (Pristina 10-11 April 2015), Conference Proceedings, Volume: I, s.463-470.

. (2011). Büyük Savaş Öncesi Üniversitelilerin Diyalog Örneği: Türk ve Romen Öğrencilerin 1914 Gezileri. Türkoloji Kültürü, c.4, sy.8, s.109-123.

(2015). Cumhuriyet'in İlk Yıllarında Balkanlarla Gayri Resmi Kültürel

Temaslar: Darülfünun Öğrencilerinin Romanya Gezisi. 7. Uluslararası Atatürk Kongresi (Üsküp-Manastır 17-22 Kasım 2011), Bildiriler, c.III, Ankara, s.1945-1970.

Özçelik, M. (2012). 1918 Bükreş Antlaşması. Turkish Studies, Volume:4/4 (Kasım/November), s.261-275.

Özel, S. (1998). Balkan ve Birinci Dünya Savaşları Arasındaki Dönemde Osmanlı Devleti Rusya İlişkileri. Ístanbul Üniversitesi Edebiyat Fakültesi Güney-Doğu Avrupa Araştırmaları Dergisi, sy.12, s.237-257.

Sancaktar, F. M. (2011). Ali Fethi (Okyar) Bey'in Bulgaristan Sefirliği Dönemindeki Faaliyetleri (Ekim 1913-Aralık 1917). Atatürk Araştırma Merkezi Dergisi, c.XXVII, sy.81 (Kasim), s.577-602.

\section{Süreli Yayınlar}

Cumhuriyet (8 Kasim 1946-19 Kasim 1946).

İkdam (23 Nisan Efrenci 1914-7 Haziran Efrenci 1914).

Peyam (22 Teşrin-i Sani Efrenci 1913-26 Teşrin-i Sani Efrenci 1913).

Sabah (23 Nisan Efrenci 1914-14 Haziran Efrenci 1914).

Tanin (28 Nisan Efrenci 1914-30 Teşrin-i Evvel Efrenci 1914).

Tasfir-i Efkar (22 Nisan 1914-16 Eylül 1914). 
Tercüman-ı Hakikat (3 Teşrin-i Sani Efrenci 1913-16 Teşrin-i Evvel Efrenci 1914). 